\author{
Marek CZAJKOWSKI \\ Jagiellonian University in Kraków \\ marek.czajkowski@uj.edu.pl
}

\title{
BALLISTIC MISSILE DEFENCE - TECHNOLOGY, EFFECTIVENESS AND ORGANIZATION - KEY ISSUES
}

ABSTRACT The article serves as an introduction to the set of papers that are devoted to the issue of ballistic missile defence as seen from the Polish perspective. It therefore refers in the most general terms to the key problems of the technology and the organization of missile defence. First of all, ballistic missiles and their strategic roles are considered as it is necessary to understand the threat before the defence against it is analyzed. Secondly, the nature of the ballistic missile defence is described, together with extensive reflections on its effectiveness. Further on the paper depicts in short missile defence systems of the world with the special attention to the United States.

Key words: International Relations, International Security, Strategic Studies, Ballistic Missile Defence, Ballistic Missiles

This article is an introductory part of the collection of four consecutive articles pertaining to the issue of missile defence. This function reflects in its form and substance, as it is supposed to provide the background for further considerations. Therefore, we are going to explain here the basic technical and organizational realities that define missile defence. It seems especially valuable, because detailed technical issues are usually omitted in general considerations or, at best, are brought to the simple tally of the armaments together with the uncritically optimistic assessment of the effectiveness of certain weapons systems. Such an attitude dominates the public and political space, especially in Poland, where real knowledge on the matter is usually juxtaposed to wishful thinking. But the technical side of the problem is by far more complicated than it is commonly understood. The more comprehensive analyses suppose rather sceptical ap- 
praisal of the capabilities of the contemporary missile defence. So, as this set of papers considers missile defence in the context of the national security of Poland it seems right to start it with the assessment that could provide such an analysis, even if short and very general one. Therefore, the main technical determinants, the current state of missile defence in the world and its effectiveness, together with the most general political and strategic realities will be mentioned in this text.

Such a technical approach is valuable especially because the technologies involved determine the basic parameters of weapon systems and that define their combat effectiveness. This in turn reflects on the tasks that a certain weapon could carry out and then on the role of missile defence as an instrument of the security policy of the state and, in many instances, of its broadly understood foreign policy as well. However obvious it might seem, the problem still persists that the technical realities determined by the related laws of physics and the capabilities of certain technologies are largely unknown to the public. It is hard to find well informed opinions even in the political discourse or within the foreign policy experts community, again especially in Poland. It is usually instinctively assumed that missile defence it is just another air defence, with some special features of course, but essentially the same in nature. Such thinking is deeply flawed, as missile defence profoundly differs from the classic air defence, much more than it is commonly believed.

Let us therefore reiterate that there is not only the need but also the necessity to detail some technical realities in order to understand the military and the political meaning of missile defence. This, however, requires a host of complex technical and organizational issues to be risen in the paper which is supposed to remain within the realm of the political science, and this is not an easy task. On the one hand, we have to address quite a complicated matter starting with reminding of the basic laws of the nature, on the other we must avoid too much technical reasoning that would likely become unclear to the reader of this journal which is devoted to the social sciences, not to the physics, engineering, technology or the military sciences.

Another difficulty is that our topic concerns the issues that are not only kept top secret but are also a subject of various disinformation activities. The latter is mainly due to the fact that missile defence is usually a very important factor in many international and internal political controversies, with economic interest and business opportunities in the background. Thus it is difficult not only to get the accurate data regarding the key technical parameters, but also to sort out the false information which exists in great abundance. Fortunately, there are many research centres and independent experts that deal with the available information and publish technical issues already processed into a more accessible form. There are also unclassified reports prepared by credible state institutions or scientific bodies that shed light on the important technical problems. This very paper is based on the selection of such sources, although we cannot always quote them directly or in full in order to avoid excessive technicality of the argument. The most important are: mostlymissiledefence.com, Missilethreat, GlobalSecurity, Arms Control Assciation, Union of Concerned Scientists, Federation of American Sci- 
entists, National Research Council of the National Academies, Defense Science Board and Congressional Research Service - there are of course many more.

The order of this article is as follows. Firstly, we describe ballistic missiles as a weapon, because their properties obviously reflect on missile defence - thus we define and describe the threat. Secondly, we discuss missile defence as such - specifically pointing out at its inherent limitations. And finally, we shortly present missile defence arsenals of the world with particular reference to the United States.

\section{BALLISTIC MISSILES - THE CHARACTER OF THE THREAT}

The first question we have to address when we start the considerations on missile defence is against what it is directed, because the defence always follows the existence of the offence. Today there is a number of weapon systems that are named by their designers, operators and owners missile defence (MD) or ballistic missile defence (BMD). ${ }^{1}$ The basic task of such systems is to destroy ballistic missiles in flight.

According to the most common definition, a ballistic missile is a rocket-propelled self-guided strategic-weapons system that follows a ballistic trajectory to deliver a payload from its launch site to a predetermined target. ${ }^{2}$ This notion is as widely accepted as it is misguiding because it is very narrow and in fact refers only to the very special kind of a ballistic missile. The more precise definition produced by the US Department of Defence states that a ballistic missile is [a]ny missile which does not rely upon aerodynamic surfaces to produce lift and consequently follows a ballistic trajectory when thrust is terminated. ${ }^{3}$ In turn, a missile is in a strict sense an object that is thrown, shot, or launched as a weapon $[. ..] .^{4}$ To clarify all those considerations we have to underline three distinct features of a ballistic missile: it is a rocket, it is a missile and it moves along a ballistic trajectory.

A rocket is a kind of vehicle which is propelled by an engine that induces its movement by a reaction force of a jet stream of hot gases produced while burning fuel with oxidizer which is carried by this very object. To describe it plainly let us point to the important difference between a rocket engine (motor) and a common airbreathing jet engine (motor). The latter gathers the oxygen for the combustion from the air it moves through, while the former carries both the fuel and the oxygen (oxydizer) in the tanks

1 Russian: противоракетная оборона - ПРО, Hebrew equivalent of the term BMD: הגנה מפני טילים French: La défense antimissile, German: Raketenabwehr.

2 "Ballistic Missile", in Encyclopaedia Britannica, 2017, at <https://www.britannica.com/technology/ ballistic-missile>, 9 February 2017.

3 “Ballistic Missile”, in DoD Dictionary, 2017, at <http://www.dtic.mil/doctrine/dod_dictionary/ data/b/2726.html>, 9 February 2017.

4 "Missile", in Dictionary by Mirram-Webster, 2017, at <https://www.merriam-webster.com/dictionary/ missile>, 9 February 2017. 
(in case of solid fuel rocket motors the mix of the fuel and the oxidizer is stored in solid state). There are three most important properties of a rocket engine:

- very high thrust-to-weight ratio, that makes it capable to move a large masses and accelerate them to high velocities,

- very high fuel consumption, what means that a launch mass of a rocket in most cases consists mainly of fuel and oxidizer that burn out relatively fast,

- it is capable to operate outside dense layers of the atmosphere and in the relative vacuum of space.

It is a missile. If a rocket is supposed to hit distant objects as a weapon it becomes a missile. We have to remember, however, that there are many other missiles that are not rocket-propelled. And there are of course many kinds of rocket-propelled missiles, missile defence deals only with some of them, namely with ballistic missiles.

A ballistic missile is a rocket-propelled missile, which travels the greatest part of its distance by the inertia, along the trajectory which is defined by the laws of Newtonian physics. In practice it means that during its relatively short work a rocket motor gives a missile desired speed and vector of movement and then it stops. The velocity, however, is already so high that the mass that remains after the burn-out of the fuel (and after the detachment of the lower stages in case of the composite missiles) covers very great distance compared to the propelled phase of the flight. For example, a ballistic missile with the range of $3000 \mathrm{~km}$ covers this distance in around 14 minutes, rising to the ceiling of some $650 \mathrm{~km}$, but the accelerated portion of the trajectory has a duration of only 80-140 seconds and extends to 100-120 kilometres - all the rest of the flight proceeds due only to the energy gathered during the acceleration phase. In case the missile has a range of $10000 \mathrm{~km}$, those values are, respectively: 30 minutes, 1300 kilometres, 170-300 seconds and 18-220 kilometres. For the missile with 300 kilometres of range it is, respectively: 4 minutes, 80 kilometres, 60-70 seconds and 25-35 kilometres. ${ }^{5}$ All the above-mentioned calculations are based on the presumption that the given missile travels along the minimum-energy trajectory, what means that its throw vector has the angle optimized to achieve the greatest distance. If this angle is greater or lesser than that, the range decreases and the highest point of the trajectory is located higher or lower. All this also implies that ballistic missiles are very fast as well, their burn-out speed varies from $1.5 \mathrm{~km} / \mathrm{sec}$ for the missiles of nominal range of 300400 kilometres to even $7 \mathrm{~km} / \mathrm{sec}$ or more for those capable to cover $12000-15000 \mathrm{~km}$.

These characteristic features of ballistic missiles are of the foremost importance from the point of view of their applications. Due to the great velocity and the high arching trajectory they are capable of delivering warheads very fast to very distant places with a great ease. It means that they can penetrate deep into the potential enemy's defensive space very effectively and avoid counteraction because they are very difficult to destroy in-flight for many reasons that will be elaborated further on. It should be strongly underlined, that this certainty to achieve the desired effect by the use of ballis-

Data according to: J.M. Lindsay, M. O'Hanlon, Defending America. The Case for Limited National Missile Defense, Washington 2001, p. 34. 
tic missiles, regardless the enemy's defence, is their most important trait and this is why their significance usually go beyond the military role on the battlefield.

To clarify and summarize to this point, it has to be said that ballistic missiles of various types and with various characteristics are of course very important instruments of warfighting of the countries that possess them. Some of the missile systems, the ones with the range of tens of kilometres or even several hundred kilometres are just the battlefield weapons, powerful but limited in use within the operational framework of the conventional conflict - they are usually called artillery-rocket systems. But other ${ }^{6}$ types, especially equipped with weapons of mass destruction (WMDs) or precision-guided munitions may become a separate and especially important instrument of security policy of a state, or even more broadly, of its foreign policy.

The illustration of this mechanism may look as follows. Country A is threatened by country $\mathrm{B}$ which has a significant number of highly precise conventionally armed ballistic missiles in its arsenal. B is therefore able to strike A's vital military and civilian targets within minutes, no matter how deep inside the territory they are located. Thus A may suffer very much without even slightest chance to avert at least the part of the damage, so it must consider that compelling fact in all its calculations vis-à-vis B. Of course, the existence of a missile defence would change this equation again, adding also to the uncertainty of the situation, as anti-missile systems are still largely unproven and in fact problematic as far as their real capabilities are considered. And this is exactly the reason why international relations, international security and strategic studies are interested in ballistic missile arsenals as tools of deterrence, coercion or intimidation and in missile defence as the instrument designed to offset the abovementioned capabilities. So let us reiterate that ballistic missiles are not just a warfighting tool but serve also as an instrument of broadly understood security and foreign policy of the state; $;^{7}$ the same refers to missile defence. ${ }^{8}$ Both are very important factors of the international stability and the balance of power on the global as well as on the regional level.

Currently there are dozens of countries and some non-state actors that possess the arsenals of ballistic missiles capable to become a political instrument in certain circumstances. We will shortly mention the most profound cases, highlighting the role of the missile stockpiles as the especially important tool. To maintain the clarity of the argument, from this point we will strictly follow the American, range based classification of ballistic missiles with the addition of the subcategory artillery-rocket systems which is important in some instances.

6 This is the theoretical classification; the real division in real situations may be blurred somehow.

7 More about the role of ballistic missiles in the states' policies, see M. Czajkowski, Obrona przeciwrakietowa w stosunkach międzynarodowych, Kraków 2013, pp. 179-205.

8 More about the role of missile defence, see ibid., pp. 204-260. 
Table 1. The classification of ballistic missiles

\begin{tabular}{|l|l|c|}
\hline ICBM & Intercontinental Ballistic Missile & Range \\
\hline IRBM & Intermediate Range Ballistic Missile & Above $5500 \mathrm{~km}$ \\
\hline MRBM & Medium Range Ballistic Missile & $3000-5500 \mathrm{~km}$ \\
\hline SRBM & Short Range Ballistic Missile & $1000-3000 \mathrm{~km}$ \\
\hline SLBM & Submarine Launched Ballistic Missile & up to $1000 \mathrm{~km}$ \\
\hline
\end{tabular}

Source: National Air and Space Intelligence Center, Ballistic and Cruise Missile Threat, Wright-Patterson AFB, Ohio, March 2006, p. 3.

USA. There is a large number of ICBMs and SLBMs in stock, that form two of the three elements of the classic strategic nuclear deterrence triad (the third leg is the force of long range bombers capable of delivering nuclear free-fall bombs and cruise missiles). They are the American ultimate safeguard on a global scale, so their basic task is to be able to perform retaliatory strike in every possible circumstance and against every enemy. Thus they fulfil a very important role in the comprehensive US deterrence strategy.

Russian Federation. ICBMs and SLBMs that Russia possess in a similar quantity as the United States, ${ }^{9}$ have the same function of the ultimate deterrent as the American counterparts. But Russia has also modern SRBM class missiles in its arsenals that may have the political importance as the deterrent in the smaller, regional scale. Their deployment at the Russian borders may also be the important factor of the foreign policy, for example it may become the instrument of exerting pressure on the neighbours. ${ }^{10}$ Those missiles can also be dispatched to various regions in the world, like recent deployment of the Iskander missiles to Syria. ${ }^{11}$ There they serve as the political safeguard of the expeditionary operations and of the growing influence, as well as the proof of the Russian determination to continue the regional engagement.

China. The People's Republic of China also owns the ICBMs and SLBMs, their inventories and capabilities increase steadily. Although smaller in number, they fulfil the same mission that their American and Russian counterparts. But China's arsenal comprises also of the large number of the MRBMs and SRBMs that may be armed with nuclear weapons or the precision-guided munitions. They have a key role within the framework of the Chinese military strategy, being also important part of the for-

9 For the exact numbers, see "New START Treaty Aggregate Numbers of Strategic Offensive Arms", Bureau of Arms Control, Verification, and Compliance, 1 April 2017, at <https://www.state.gov/t/avc/ newstart/269406.htm>, 7 April 2017.

10 V. Gera, J. Heintz, "Baltic Region Worried about Russian Missiles in Kaliningrad”, U.S. News, 8 October 2016, at <http://www.usnews.com/news/world/articles/2016-10-08/poland-concerned-aboutrussian-missiles-sent-to-kaliningrad>, 8 January 2017.

11 B. Opall-Rome, "Israeli Satellite Imagery Shows Russian Nuclear-Capable Missiles in Syria”, Defense News, 6 January 2017, at <http://www.defensenews.com/articles/israeli-satellite-imagary-showsrussian-nuclear-capable-missiles-in-syria>, 8 January 2017. 
eign policy of Beijing which is oriented to deny or at least to complicate foreign armed forces access to some crucial areas not only within but also outside the country's borders. The implementation of this strategy, termed Anti-Access/Area Denial (A2/AD), means that China is trying to exert its influence in the more and more remote regions through making them be accessible only by own armed forces. This strategy is aimed chiefly against the United States and the Chinese rocket force has its role here, as it is ready to attack the key American installations on the Far Eastern theatre, together with American aircraft carriers and the satellite systems. By doing so Beijing would be capable to impede the execution of the operational freedom of the US forces in the region and around it. The effectiveness of this strategy depends of course on the capability of the American missile defence deployed on the theatre to defeat Chinese missile should such need arise - this is not clear as of today, the whole issue will be discussed below.

India. This country has a significant number of relatively modern SRBMs, MRBMs and IRBMs; there are also ICBMs and SLBMs in development. The main task of this arsenal is to form the core of the strategic deterrence policy that is directed against Pakistan and China, although it does not yet match more capable missile force of the latter. ${ }^{12}$ What is more, quick and comprehensive development of missile and space technology is very important part of the strategy to build the modern indigenous industrial base. It adds profoundly to the international prestige of India as well.

Pakistan. The main strategic foe of this country is undoubtedly India, therefore its MRBM and SRBM together with nuclear weapons pose mainly as a deterrent. They are a sort of the ultimate argument against the enemy which is otherwise superior by every military and economic standard, save the possession of the weapons of mass destruction. But if the weapons of mass destruction are to secure Pakistan's safety they must be deliverable in every circumstance. With the overall superiority of India's military, ballistic missiles are the obvious choice as the most effective deterrent. This case shows very clearly the essence of the importance of ballistic missiles.

Iran. Teheran considers its growing and steadily modernizing arsenal of SRBMs and MRBMs, together with the development of the IRBM, and perhaps even the ICBM, an asymmetric response to the military predominance of the USA, Israel and the Persian Gulf states. ${ }^{13}$ It is supposed on the one hand to deter the enemies and to be an instrument of coercion within the offensive strategies ${ }^{14}$ on the other. Iran frequently underlines that there are at least 35 American military installations within the range of its

12 S. Thaliyakkatti, Chinese Perceptions on India's Long Range Missile Development: How Credible is India's Deterrence against China?, ISAS Working Paper, no. 258, 24 April 2017, Institute of South Asian Studies, National University of Singapore, at <https://www.isas.nus.edu.sg/ISAS\%20Reports/ ISAS\%20Working\%20Papers\%20No.\%20258-Chinese\%20Perceptions\%20on\%20India's\%20Long\%20 Range\%20Missile\%20Development.pdf>, 15 May 2017.

13 M. Elleman, W. Alsayed, "Ballistic Missile Defense Cooperation in the Arabian Gulf", in C.M. Kelleher, P. Dombrowski (eds.), Regional Missile Defense from a Global Perspective, Stanford 2015, p. 179.

14 P. Izewicz, Iran's Ballistic Missile Programme. Its Status and the Way Forward, EU Non-Proliferation Papers, No. 57, SIPRI, Stockholm, April 2017. 
missiles; ${ }^{15}$ there are also advanced development efforts to construct the anti-ship ballistic missile. ${ }^{16}$ This approach closely resembles the Chinese strategy with respect to that.

North Korea. Korean missile stockpile consists of SRBMs and MRBMs, but this country does not hide that it is developing the ICBM class weapon and possibly even the anti-ship ballistic missile. In the security strategy of Pyongyang ballistic missiles are of the paramount importance ${ }^{17}$ - they are supposed to deter the United States by threatening the US armed forces, the American allies in the region (Republic of Korea and Japan) and, potentially, even the territory of the USA. ${ }^{18}$ Nuclear weapons, which North Korea is developing constantly and openly, are immanent part of this threat. The most recent developments clearly indicate the increasing capability of the increasingly diverse and versatile Korean missile force, ${ }^{19}$ highlighted by the apparently successful test of the missile which falls in the category of the ICBM with its calculated range of $6700 \mathrm{~km}^{20}$

Israel. Israeli missiles that belong to the MRBM and IRBM classes, perhaps also supplemented by the ICBMs, are important part of the nuclear deterrence against the unfriendly Arab states and Iran. The quick response time, i.e. very short period between the decision to do so and the actual launch of the missile is extremely important, having in mind Israel's uncomfortable geostrategic position.

Hamas, Hezbollah and other anti-Israel militant groups. These organizations possess large numbers of unguided ballistic missiles that may be labelled artillery-rocket systems, with ranges varying from a few to over a hundred kilometres. Despite the limited range, the lack of guidance systems and the conventional warheads, those weapons form the important part of the asymmetric war between Israel and these non-state actors, and the rockets were used as counter-value instruments - that is, to hurt and harass the civilian population [...]. ${ }^{21}$ It is because the military and strategic realities of Israel make the

15 “Commander: IRGC Will Destroy 35 US Bases in Region if Attacked", Fars News Agency, 4 July 2012, at <http://english2.farsnews.com/newstext.php?nn=9103084990>, 8 January 2017.

16 J. Binnie, “Iran Successfully Tests Radar-Guided Anti-Ship Ballistic Missile”, IHS Jane’s 360, 10 March 2017, at <http://www.janes.com/article/68625/iran-successfully-tests-radar-guided-anti-ship-ballisticmissile>, 7 April 2017.

17 J. Lewis, “Kim Jong Un's Quest for an ICBM", Foreign Affairs, 9 June 2017, at <https://www. foreignaffairs.com/articles/north-korea/2017-06-09/kim-jong-uns-quest-icbm?cid=intlea\&pgtype $=$ hpg $>, 10$ June 2017.

18 More about the role of the North Korean missile arsenal, see M. Czajkowski, "Korea Północna vs. BMDS", in W. Sokała, B. Zapała (eds.), Asymetria i hybrydowość - stare armie wobec nowych konfliktów, Warszawa 2011, pp. 65-70.

19 I. Williams, T. Karako, "North Korea’s New Missiles on Parade", Center for Strategic \& International Studies, 18 April 2017, at <https://www.csis.org/analysis/north-koreas-new-missiles-parade>, 20 April 2017.

20 D. Wright, "North Korea Appears to Launch Missile with 6,700 km Range”, (Blog) All Things Nuclear, Union of Concerned Scientists, 3 July 2017, at <http://allthingsnuclear.org/dwright/north-koreaappears-to-launch-missile-with-6700-km-range>, 6 July 2017.

21 A. Levite, S. Brom, "From Dream to Reality", in C.M. Kelleher, P. Dombrowski (eds.), Regional Missile Defense..., p. 138. 
very special tool out of those relatively not so powerful weapons. ${ }^{22}$ Israel assesses that the stockpile of the Hezbollah alone consists of 100000 missiles. ${ }^{23}$ Currently anti-Israel groups are in the process of acquiring more potent weapons systems with greater range and fitted with guidance systems that should be classified as SRBMs. Probably some of them have the range of even $700 \mathrm{~km} .^{24}$

Others. Ballistic missiles of the SRBM class are stockpiled in the arsenals of many countries and non-state actors, especially in the Middle East and across the post-Soviet space. Most of them, however, are relatively out-of-date Soviet models designed during the ' 50 of the $20^{\text {th }}$ century. Some of them are domestically modernized end then exported by such countries like North Korea or Iran, some originate from China. Despite this technical backwardness, all those missiles can easily become a political instrument of the sort we have described above, if they are successfully equipped with WMD or precision-strike munitions. There are also some instances of modern and very capable missiles, like Saudi Arabia that owns Chinese made MRBMs DF-21, ${ }^{25}$ or Armenia, that has recently acquired Iskander SRBMs from Russia. ${ }^{26}$ In both cases the deterrent role of those weapons is quite clear.

Summarizing, according to the official assessments by the US authorities, outside the arsenals of the NATO countries, China and Russia there are well over 7000 ballistic missiles of the SRBM class or bigger - by the end of the decade this number is supposed to reach $8000 .{ }^{27}$ Apart from this, many countries possess large quantities of artilleryrocket systems, but they are not relevant from our point of view, because of lack of the special political importance - save the arsenals of the anti-Israel militant groups.

22 M. Czajkowski, Obrona..., pp. 149-152.

23 "Israel: Any War with Hezbollah Will Be Devastating", Al Jazeera, 20 April 2016, at <http://www. aljazeera.com/news/2016/04/israel-war-hezbollah-devastating-160420183832190.html>, 8 January 2016.

24 Russian made Scud-D missiles, allegedly transferred to Hezbollah from Syria, see A. Barnard, E. Schmitt, "Hezbollah Moving Long-Range Missiles from Syria to Lebanon, an Analyst Says", New York Times, 2 January 2014, at <https://www.nytimes.com/2014/01/03/world/middleeast/hezbollahis-said-to-transfer-missiles.html?_r=0>, 9 May 2017.

25 J. Lewis, “Why Did Saudi Arabia Buy Chinese Missiles?”, Foreign Policy, 30 January 2014, at <http:// foreignpolicy.com/2014/01/30/why-did-saudi-arabia-buy-chinese-missiles/>, 8 January 2017.

26 Z. Shiriyev, “Azerbaijan's Possible Reactions to Armenia’s Iskanders: Defense Versus Offense”, Eurasia Daily Monitor, vol. 13, no. 160 (5 October 2016), at <https://jamestown.org/program/azerbaijanspossible-reactions-armenias-iskanders-defense-versus-offense/\#sthash.fsQvtrgA.dpuf >, 8 January 2017.

27 According to the Missile Defense Agency, see J.D. Syring, Ballistic Missile Defense Overiew, Missile Defense Agency, 14 August 2013, at <https://pl.scribd.com/document/176023320/Ballistic-MissileDefence-Overview $>, 8$ January 2017. 


\section{THE NATURE OF MISSILE DEFENCE}

It has already been stated that the properties of ballistic missiles make them extremely difficult to counter - and this is obviously one of their most important features. It stems out of the following:

- high velocity of ballistic missiles is very high in comparison to distances they cover; therefore, when they enter the detection range and subsequently the firing range of the defence system the time that remains for it to react is relatively short,

- velocity of ballistic missiles requires use of the interceptors which are also very fast and which have the ability to conduct very accurate and extremely quick manoeuvres,

- high altitudes of ballistic missiles' trajectories add up to the fact that they are in range of classic endo-atmospheric air-defence weapons for very short time - deployment of multiple lines of defences against ballistic missiles calls for the weapons systems capable to operate within very high layers of the atmosphere or even outside of it,

- ballistic missiles or their independently travelling warheads are relatively small targets and it also adds to the difficulty of countering them in all phases, from the detection, through the whole process of the target acquisition and calculation of the fire solution to the interception sequence.

Because of all the above-mentioned technical parameters a ballistic missile is an offensive weapon that maintains overall superiority over defensive systems. This situation persists from the moment ballistic missiles were used for the very first time as the instrument meant to deliver the strategic impact on the enemy during the World War II. Since some 5500 A-4/V-1 rockets were used by the Germans between September 1944 and March 1945, ballistic missiles remain the weapon that is extremely difficult to cope with. Save one very specific example, there is virtually no defence system capable of defeating ballistic missiles effectively enough that it would be comparable to other current defensive weapons such as anti-tank or anti-aircraft systems. ${ }^{28}$ And it is despite the fact that since 1945 missile defence was one of the centrepieces of the strategic planning and vast amounts of money have been poured into its development over decades, especially in USA and USSR.

The $21^{\text {st }}$ century did bring some new technologies that could be used to intercept at least certain kinds of ballistic missiles. But on the other hand we are witnessing a constant development of rocketry that nullifies that progress to great extent, rendering missile defence still unreliable. Over the decades ballistic missiles have become more and more resistant to defence, which adds up to their already mentioned properties that come out of the general laws of physics. The development of the strategies and the technologies designed to overcome missile defence started as early as in the sixties of the $20^{\text {th }}$ century and soon yielded considerable effect. Thus, already over half a century ago many types of ballistic missiles were routinely equipped with the devices called penetra-

28 More on the development of missile defence, see M. Czajkowski, Obrona..., pp. 93-145. 
tion aids (penaids), designed to overcome missile defence. Special strategies supposed to help the missiles go through were also being perfected through the decades.

Thus, ironically, there is an important asymmetry in the development process and current state of ballistic missiles versus missile defence. The former were being perfected for a long time, with special attention to their capabilities to overcome the defences that until today, have not materialized in the military relevant form. The latter was being developed simultaneously, but only today it has reached the stage of deployed weapons systems supposed to be effective to an extent. So, while still in statu nascendi missile defence has to stand up against the huge obstacle of experience with its penetration that has been accumulated over the decades.

In short and without details, the technical means designed to overcome missile defence are as follows: ${ }^{29}$

- decoys are the objects that defence sees as identical to the actual rocket or warhead; missile might deploy them in significant number to compel defence to multiply the number of interceptors fired; there are many kinds of decoys and their effectiveness differs, but is generally considered high - the simplest of them, as some analyses hold, are available for the installation even on board of the relatively unsophisticated ballistic missiles, ${ }^{30}$

- jamming devices that may be fitted on missiles, their upper stages or on the warheads to distort radar or thermal tracking and targeting systems,

- stealth technologies or the other means of camouflaging missiles or their warheads may also be employed to protect them from the detection or to make the tracking and targeting more difficult.

Besides the technical means of overcoming missile defence there are also certain strategies that may be applied to enhance the effectiveness of ballistic missiles. The most important are:

- a missile, its upper stage or even the single warhead may manoeuvre on its flight to conduct course corrections; even the slightest change of the missile's trajectory compels the defence to recalculate tracking or targeting, thus delaying the moment when the fire solution is computed and shortening the time left for the interception; it may even force the repetition of the whole process, even several times, finally wrecking all the defence action and even causing the waste of the interceptor units,

- if there are more ballistic missiles available for the attack, some of them may be directed to blind the radar and other surveillance, tracking and targeting systems by the multimegaton nuclear blast in the stratosphere - it is one of the most effective countermeasures,

- missile force may use multiple attack patterns designed to impede defence, especially by the way of cutting the time left for defence actions - there may be other than

29 More on this, see comprehensive technical analysis in: A.M. Sessler at al., Countermeasures. A Technical Evaluation of the Operational Effectiveness of the Planned US National Missile Defense System, Union of Concerned Scientists, Cambridge, Mass. 2000, at <https://drum.lib.umd.edu/bitstream/handle /1903/4333/2000-UCS-CM.pdf ?sequence=1\&isAllowed=y>, 25 April 2017. 
minimum energy trajectories employed, like lofted or depressed ones; a missile may even enter the low orbit instead of travelling along the ballistic curve that would allow it to appear over the radar horizon of the defence very late, ${ }^{31}$

- the offensive side may also decide to allocate the missiles in several waves where the first few would be designed specifically to destroy or saturate the defences - additionally it may concentrate on some selected area in order to make a local breakthrough by saturation and by doing this it could achieve the strategic objective.

It is worth noting that all of those means and strategies are relatively unsophisticated, at least the simplest of them. It is generally understood that the penaids, not to mention attack strategies, are generally easier to develop than missile defence. And that is precisely why ballistic missiles, those which can apply means and methods to overcome missile defence, are still way ahead of defensive capabilities. It is even argued, and it is an argument which is convincing to some extent that this state of affairs is an immanent feature of certain technologies and their combinations and it is rather impossible to change. ${ }^{32}$

It is necessary to underline at this point that every country that relies on ballistic missiles in its defensive or offensive strategies and therefore regard them as the special tool of the security policy, would certainly do everything to ensure its rocket force retain its value. Thus it would undoubtedly use every available method to enhance the accuracy, penetration capability and the survivalability of the whole arsenal. It would do its best to ensure the other actors of the international stage that its missile force is fully capable to fulfill its mission regardless of all the defence. So, in the peacetime or during the international crisis the owner of a missile arsenal would surely be developing the technologies and strategies and would be strengthening the organization, morale and the training of the missile force to stay ahead of the potential opponent's missile defence development. One of important ways to achieve this goal is the development of the comprehensive strategies to defeat missile defence in the very first hours of the conflict by a concentrated effort of different combat platforms such as the cruise missiles together with the possible commando raids and cyber and electronic warfare.

The last issue is certainly worth elaborating. It is commonly believed that in the combat situation missile defence would face ballistic missiles together with their penetration techniques and strategies in a sort of the duel. But in the reality of the actual conflict missile defence with its own protective force would be faced not only by the enemy's missiles but also by wide-range multi-spectral counterforce attack relentlessly exploiting its inherent vulnerabilities. The newest weapon which might be used to counter missile defence is currently entering the advanced testing phase in Russia and China and it will probably enter service in the near future. It comprises of warheads

31 Such a strategy is called fractional orbit bombardment and is especially effective at great distances of the attack which would otherwise require very high altitude of ballistic flight instead of fractional orbit which may be set as low as $150 \mathrm{~km}$ over the Earth's surface or even lower. 
with hypersonic propulsion launched atop ICBMs that can attack at great speed and at relatively low altitudes with the capability to execute aggressive maneuvers. ${ }^{33}$

In short, there is multi-faceted offence vs. defence arms race and ballistic missiles, modern and sophisticated ones operated by modern and well organized militaries, are way ahead every missile defence that is deployable now or would be in the foreseeable future.

The other problem that affects the effectiveness of missile defence is obviously the economic dimension of the development, deployment and maintenance of the sufficient defensive force, because as there are the most advanced technologies involved, the costs are very high. Missile defence is substantially more expensive than classic air defence and that limits the number of the sensors and interceptors which can be bought in certain economic circumstances. But here come the numbers:

- as multiple interceptors are routinely launched against one target, the inventory of missile defence assets must in theory be at least twofold larger than the whole missile force of the potential enemy,

- add maneuvers, decoys and other countermeasures that foil the defences and make it use even more munitions, the defensive arsenal multiplies again,

- the more advanced the force that the opponent wields, the larger anti-missile stockpile is necessary.

But it is not all. In case of the vast territory it should also be considered that the enemy may use the saturation tactics, sending its forces against selected targets. It means that to make it effective, every single part or the territory must be protected by missile defence systems many times bigger in numbers that the missile force of the enemy. How high the other multiplier is depends on the technical data of the defence systems in terms of effective firing range versus missile's velocity.

All in all, every missile defence must be much larger in numbers than the arsenal it is supposed to counter. Finally, it may be too much a burden for certain country, even a rich one. That is why it is usually argued that missile defence is crafted against limited targets, in fact no one has ever seriously thought about a total missile defence, and the reason for that is in fact mostly economic.

Summarizing to that point, main impediments to the development of missile defence as an effective and reliable weapon are by their nature both technological and economic. Both dimensions are also very strictly linked together because the state-of-the art technology yields costs. This is of course relative to mission certainty an anti-missile system is supposed to fulfill in the given realities, determined by the size and the quality of the opposing missile force.

All the above mentioned difficulties were conceptualized as early as the late sixties when the construction of the strategic missile defence systems Sentinel ${ }^{34}$ and sub-

33 See for example G. Noris, “Classified Report on Hypersonics Says U.S. Lacking Urgency”, Aviation Week \& Space Technology, 14 February 2017, at <http://aviationweek.com/defense/classified-reporthypersonics-says-us-lacking-urgency>, 14 February 2017.

34 See the seminal article R.L. Garwin, H. Bethe, "Anti-Ballistic-Missile Systems", Scientific American, vol. 218 , no. 3 (1968). 
sequently Safeguard was debated in the United States. Scientists and politicians were pointing to material limitations that rendered missile defence ineffective in the light of the economic impediments and strategic realities. ${ }^{35}$ The sole strategic system which was eventually build for several billion dollars, Safeguard, was designed only to defend a small portion of the US nuclear deterrence force as the part of the overall effort to retain and enhance its survivalability. The fact that it was also highly vulnerable to the enemy's countermeasures and saturation attack lowered Safeguard's military significance even more. No wonder that the decision to dismantle the system was made by the Congress on October 2, 1975, just one day after it was officially introduced into the combat readiness. ${ }^{36}$

The reservations voiced over half the century ago are quite accurate today, though many of the corresponding circumstances have changed, especially the general equation: ballistic missiles versus missile defence. In the sixties, the missile threat first of all had the form the strategic nuclear offensive weapons that were in possession of the superpowers alone (with China slowly joining but still way behind). Those powers were not only producing vast amounts of delivery systems and nuclear payloads, but were also capable to continuously upgrade and deploy new systems with enhanced penetration aids. The subsequent generations of missile defence systems conceived during those years were being designed to counter this threat and thus were attributed with the term 'strategic'. Today the missile threat is profoundly more diverse in the quality, quantity and the nature of the military and the political missions the missile force of a certain nation have to fulfil.

On the other hand, the research conducted throughout the decades has led to practical applications of the new technologies which in turn resulted in the construction of the weapons able to intercept at least some kinds of ballistic missiles. More precisely, the development of radiolocation technologies, electronics, optronics and computers together with the creation of the new construction materials allowed to design and field the sensors and weapons systems that can be used to defeat ballistic missiles, within the substantial limitations elaborated below.

Missile defence systems that are currently in active service are designed along the same general principle: radar stations supplemented with infrared and optical sensors detect, track and target ballistic missiles that are subsequently destroyed by anti-missile rockets. The differences among the existing systems lay in the parameters of certain sensors, interceptors and the command and control units, such as: wavelength on which the radar stations operate, power of the emitters, gain of the receivers, range and speed, agility and the capability to acquire targets by the interceptors, processing speed of computers and capacity of the communication lines. These differences reflect mostly the ability of given defence system to destroy certain class or classes of ballistic missiles and the ability of missiles to penetrate given defences. Defensive systems may also be

35 See for example A. Chayes, J.B. Wiesner (eds.), ABM. An Evaluation of the Decision to Deploy Antiballistic Missile System, London 1970, first published in the USA in 1969. 
compiled into a vertically layered structure, where a certain area is protected by the multiple weapons systems. In such a case different types of weapons are tasked either to be deployed against different threats or to be deployed subsequently against one threat as it passes through the layers of the defence.

As it was mentioned above, certain weapon systems are designed to engage a certain range of targets. As we deem this fact very important, we will now present two examples of well-known systems and their basic applications in some detail.

First of them is the American air defence system Patriot, the PAC-3 variant which is designed to use the interceptor missile MIM-104F (also referred to as PAC-3) dedicated to anti-missile warfare. The system is able to defeat only the SRBMs within thick layers of atmosphere with the operational ceiling of $20 \mathrm{~km}$ and at the range of $40 \mathrm{~km} .{ }^{37}$ The other classes of the missiles are too fast for the Patriot - it is not able to calculate fire solution within the range of the fire control station and execute the interception sequence within the range of its interceptor. Some sources indicate that PAC-3 has a limited ability to engage MRBMs and this means that the successful intercept of the missile of that class by Patriot is possible only in certain tactical situations, relative to the location of the missile's target with respect to the launcher, its speed and the vector of the flight path.

The second example is also American Aegis BMD weapons system with its Standard Missile-3 (SM-3). In its current stage of the development it is able to defeat SRBMs and MRBMs in every circumstance, with the limited ability to engage IRBMs as well. The range of the missile of the fielded versions block IA and block IB is several hundred kilometres and the ceiling about $150 \mathrm{~km}$.

The weapons systems mentioned in the examples above may also be combined into a layered structure where the SM-3s engage the volleys of SRBMs or MRBMs outside the atmosphere and then Patriots are used to intercept the remaining SRBMs, and, if the tactical situation allows, the MRBMs as well.

The problem with the reaction time is common to all missile defence systems no matter what kind of missiles it is supposed to counter. Some answer to it comes from network-centric organization of defensive force that would allow targeting the interceptors via a remote sensor array or guidance system of the platform other than the one that actually launched it. This is the core of the upcoming American systems that are currently close to the acquiring this capability. But this concept adds to the technological complexity of the whole system because it must be deployed across wide areas in order to cover the possible flight paths of incoming missiles far enough to make this capability be relevant. Such a solution certainly aggravates the economic burden of missile defence.

We must stress at this point, that even the most modern and highly sophisticated missile defence systems still have their significant limitations that reflect the same reservations that Garwin and Bethe pointed to in 1967 in the paper mentioned above.

37 “Patriot PAC-3", Military Today, 2017, at <http://www.military-today.com/missiles/patriot_pac3. htm>, 9 February 2017. 
Penetration aids and attack strategies evolve constantly, as well as the means and tactics to engage and destroy missile defence itself, thus the impediments to countering the ballistic missile are still in place, or may even be rising.

But here we come to the differentiation of missile arsenals that is important from the point of view of the modern missile defence and its role in the security strategies and the foreign policies of given states. Today the missile threat is not only a global one that concerns the very existence of the civilization, but also has regional and even local dimension, as we have mentioned it describing the roles of ballistic missiles in the politics of different countries. Let us remind that today there are both the most modern and very primitive ballistic missiles in the stockpiles along with the whole range of the types that may be classified in between of those two. Therefore the problem of missile defence is very diverse, starting from the global plane, through transregional, regional, subregional and local dimensions. In all those perspectives, in different areas there are different missiles to be reckoned with, from the huge ICBMs to garage-made artillery rockets. That also overlaps with the level of technical sophistication of the missiles that means, from the point of view of missile defence, the penetration capabilities.

Thus, in every given instance the quantitative and qualitative value of the missile arsenal must be projected onto the economic capability of the given state to withstand the financial burden of the required missile defence. And here we come to the crucial conclusion, that the potential and actual effectiveness of missile defence and so its role in the state's policies may vary strongly and depends on a generally simple calculus: actual threat vs. defence capabilities. What has to be considered firstplace is the actual destructive power of a missile arsenal in comparison to the existing critical targets. It strictly determines what portion of the every possible attack may be 'let pass' by the defence. Plainly speaking, it means that it is necessary to calculate what percentage of the missiles may go through without crippling the defender beyond the accepted level. This calculation becomes very difficult and the error margin comes close to zero in case when nuclear weapon is considered. Therefore, if to quote a noted American weapons expert: although it is likely that defenses can achieve some degree of effectiveness against shorter-range, conventionally armed missiles, for the key mission of defense against longrange nuclear-armed missiles, the potential effectiveness of missile defenses remains unproven. ${ }^{38}$

If to make a conclusion concerning the problem of effectiveness, we might observe most generally, that modern missile defence (the types that are fielded now or are to be introduced soon) may counter qualitatively and quantitatively limited ballistic missile threats. It refers to the missiles that do not apply sophisticated penetration techniques and strategies and, cumulatively, are not deployed in the number enough to saturate the defences, both overall and locally. It is the most general observation that applies to every situation in the world where there is the missile threat and the defence to counter it. More specifically, it should be stressed that the modern ballistic missiles that

38 G.N. Lewis, “Technical Controversy: Can Missile Defense Work?”, in M. Kelleher, P. Dombrowski (eds.), Regional Missile Defense..., p. 63. 
are capable to deploy a whole range of penaids and are able to attack with the use of the sophisticated tactics are extremely difficult to defeat. And it is going to remain so in the foreseeable future. Additionally it is expectable that the eventual ballistic missile offensives would always be accompanied with the attempt to destroy or otherwise eliminate missile defence assets by the concentrated effort with the use of diverse means and methods of warfare. Especially during broad and complex military campaigns, the elimination of the opponent's missile defence would be surely one of the first operational goals.

On the other hand, there is research effort underway to enhance missile defence, especially in its ability to counter penetration techniques and strategies. It concerns both the detection/tracking/discrimination/targeting capabilities and the interception techniques of weapons systems. Right now it is relatively difficult to predict what way the relation between the missiles penetration capabilities and the defence abilities to counter it would evolve in the future, because we do not know what kind of technological breakthroughs would occur. But, what is otherwise quite obvious, the qualitative change in the available technologies must take place in order to change current advantage of the missiles over the defence. There are, of course, some promising technologies under development, such as directed energy weapons or electromagnetic weapons that would theoretically allow rapid change in missile defence effectiveness but their real combat potential is unknown now.

\section{MISSILE DEFENCE IN THE WORLD}

The following presentation of missile defence systems of the world contains the facts that are present in the public information space. But we have to remember that many of the key parameters of certain types of weapons are considered top secret, so the picture is not complete. We will briefly describe the main systems of the main countries (save the USA that is mentioned in more detail in the next chapter). We will also refer in short to the mission that missile defence has to fulfil within the strategies of those countries.

Israel. The Jewish State is confronted with the threat of the SRBM/MRBM arsenals of its neighbours, especially with the vast force of the Iranian missiles, as well as with the huge stockpile of the artillery rocket systems that are in the possession of the anti-Israeli militant groups. The latter is of significant strategic importance due to the particular geographic determinants of the Tel-Aviv's security politics. ${ }^{39}$ Generally speaking, the Israeli missile defence is the indispensable answer to the build-up of enemy's capabilities that could effectively offset the overall military preponderance of

39 See M. Czajkowski, “Obrona przeciwrakietowa Izraela”, in R. Kłosowicz, B. Szlachta, J.J. Węc (eds.), Dylematy strategiczne XXI wieku. Ksiega Jubileuszowa dedykowana Profesorowi Michatowi Chorośnickiemu z okazji czterdziestolecia pracy naukowej, Kraków 2013, pp. 221-235. 
Israel in the region. It is then considered a very important instrument of the local strategic balance.

The multitude of threats with very specific features compelled Israel to develop multi-layered missile defence that starts from the Iron Dome ${ }^{40}$ system that is designed to intercept missiles fired from artillery rocket systems. Its currently fielded variants are capable of shooting down the rockets with the range up to $70 \mathrm{~km}$ and this task has been fulfilled with great success since April 2011. Unique technologies applied in this design make itsome $80-90 \%$ combat effective. It is being used on regular basis against harassing attacks of anti-Israeli militants and at times against barrages of missiles that occur during the more intense hostilities. For example, throughout the operation Protective Edge that lasted between July $8^{\text {th }}$ and September $26^{\text {th }}, 2014$ Hamas fired over 4500 rockets against Israeli targets. Among them only 700 did actually approach residence areas and therefore required interception - according to the official statements $90 \%$ of them were shot down by the Iron Dome. ${ }^{41}$ As of August 2016, there were 10 batteries in service - everyone is equipped with 3 or 4 launchers with the complement of the 20 Tamir missiles each. ${ }^{42}$ To date Iron Dome is the only one missile defence system in the world with the capability to fulfil designed task comprehensively and proven in combat.

The higher layer of the Israeli missile defence comprises of the recently introduced multi-role air and missile defence system David's Sling. ${ }^{43}$ Its task is to intercept an airbreathing target of every kind and ballistic missiles of the 40-300 km range. ${ }^{44}$ In practice it is supposed to defeat artillery rocket systems of greater range and small SRBMs, for example of the Scud family, abundant in the arsenals of Israel's neighbours, apparently in possession of Hezbollah as well.

The next fielded system is Arrow- $2^{45}$ that is designed to intercept SRBMs and MRBMs, especially Iranian Shahab-3 MRBMs, ${ }^{46}$ at high altitudes up to $50 \mathrm{~km}$. Currently there are 2-3 batteries of that type in service, ${ }^{47}$ one of them was used to intercept

40 כיפת ברזל (Kipat Barzel) in Hebrew, the English name is the most widely used.

41 A. Ben David, “Iron Dome Blunts 90\% of Enemy Rockets", Aviation Week \& Space Technology, 1 September 2014, at <http://aviationweek.com/defense/iron-dome-blunts-90-enemy-rockets>, 6 January 2017.

42 J. Lokshin, "Iron Dome (Israel)", Missile Defence Advocacy Alliance, August 2016, at <http:// missiledefenseadvocacy.org/missile-defense-systems-2/allied-air-and-missile-defense-systems/alliedintercept-systems-coming-soon/iron-dome-israel/>, 6 January 2017.

43 קלע דוד (Keleh David) in Hebrew, but the English name is the most widely used.

44 J. Lokshin, “David's Sling (Israel)", Missile Defence Advocacy Alliance, August 2016, at <http:// missiledefenseadvocacy.org/missile-defense-systems-2/allied-air-and-missile-defense-systems/alliedintercept-systems-coming-soon/davids-sling-israel/>, 6 January 2017.

ח 45 (Chetz) in Hebrew, but the English name is the most widely used.

46 R. Haddick, “This Is Not a Test", Foreign Policy, 17 August 2012, at < http://www.foreignpolicy.com/ $\operatorname{articles} / 2012 / 08 / 17 /$ this_is_not_a_test $>, 12$ September 2011.

47 Z. Berger, "Arrow (Israel)", Missile Defence Advocacy Alliance, September 2016, at <http:// missiledefenseadvocacy.org/missile-defense-systems-2/allied-air-and-missile-defense-systems/alliedintercept-systems-coming-soon/arrow-israel/>, 21 January 2017. 
Syrian air-to-air missile that entered Israeli airspace on March 17,$2017 ;{ }^{48}$ it was the baptism of fire of this system.

The highest layer of Israeli missile defence is Arrow-3, capable to intercept warheads of the MRBMs and probably even IRBMs outside the atmosphere. The initial operational capability of this system has been announced on 18 January 2017.49

Western Europe. The European members of NATO have two weapons systems that may be used against ballistic missiles. First is the Patriot that is represented by two variants: PAC-2 which is basically air defence weapon but has limited capabilities to engage SRBMs and PAC-3 that has already been mentioned before. The second system with roughly similar anti-ballistic capabilities is $\mathrm{SAMP} / \mathrm{T},{ }^{50}$ designed in Franco-Italian cooperation. Its land version is called Mamba and it is basically a modern air defence system, that thanks to the missile Aster 30 it is able to intercept SRBMs, and it may have a limited capability against MRBMs, although the latter has never been tested. It is worth noting that in contrast to the American counterpart, SAMP/T deploys the same missile against air-breathing and ballistic targets. France has 10 batteries and Italy $5^{51}$ of Mamba, the system is also offered for export. Its maritime variant is called PAAMS $^{52}$ and in the version that includes Aster 30 missile it is installed on the ships of French, Italian and British navies, giving them the same anti-ballistic capabilities.

There is another type of missile defence weapons system, although it has not been fully developed yet, named MEADS, ${ }^{53}$ designed in the German-Italian-American cooperation. It was supposed to be the continuation and supplement to the Patriot and $\mathrm{SAMP} / \mathrm{T}$ in the air and missile defence of partner countries, combining European radar technology with the American PAC-3 missile. The program went through various difficulties, including the withdrawal of the American side from its financing, but finally the system has been selected by Germany as a replacement of the currently used Patriots. ${ }^{54}$ MEADS is also offered for export.

The NATO countries also developed a common project termed Active Layered Theatre Ballistic Missile Defence (ALTBMD), which was not a weapon system as such but rather a structure within the NATO framework. It was tasked with the development of the doctrine, planning and training of those elements of the Allied armed

48 A. Harel, G. Cohen, J. Khoury, “Israeli Air Force Strikes Targets in Syria; Assad Forces Threaten 'Direct' Retaliation”, Haaretz, 17 March 2017, at <http://www.haaretz.com/israel-news/1.777902>, 18 March 2017. at <http://www.janes.com/article/58841/france-receives-last-samp-t-air-defence-system>, 21 January 2017.

52 Principal Air-to-Air Missile System.

53 Medium-Extedned Range Air Defense System.

54 M. Dura, "Niemcy: Umowa na system MEADS w przyszłym roku?", Defence24, 14 July 2016, at <http://www.defence24.pl/408446,niemcy-umowa-na-system-meads-w-przyszlym-roku>, 7 January 2017. 
forces that were involved in missile defence efforts - it was then the integration structure built over the national units. Initially NATO envisioned only the limited defence of its armed forces deployed at the theatre - hence the name of the effort. However later on, at the Lisbon summit in 2010, the creation of a defence of the whole Alliance's territory in Europe was established. Gradually, theatre defence programme was merged within awider approach termed NATO Ballistic Missile Defence. The Lisbon summit also declared that the NATO Integrated Air Defence System (NATINADS), operational since 1961, would be transformed into the effort called NATO Integrated Air and Missile Defence (NIAMD), according to the holistic vision of comprehensive defence against all kinds of threats. When the NATO Ballistic Missile Defence was declared operational in July 2016, the NATO Integrated Air and Missile Defence System (NATINAMDS) became the reality. The system comprises of numerous assets assigned by the member states, interconnected to form the unified structure. The American European Phased Adaptive Program (EPAA), together with some other countries' sensors is the key part of the territorial defence, while the other countries' missile defence units may be used as a theatre defence.

All this effort is directed chiefly against potential limited threats from the Middle East or elsewhere, but not against the Russian vast missile arsenal, although it is often portrayed as such. The limited number of missile defence assets and the specifications of the Russian modern missiles cannot shift the strategic balance between NATO and the Russian Federation.

Russian Federation. Missile defence is not treated in Russia as an independent military instrument. The only dedicated missile defence system is the cold war legacy A-135 Moscow defence perimeter, ineffective and partially deactivated. Apart from this within the structures of the Land Forces, The Navy and the Aerospace Force ${ }^{55}$ there is a vast number of the S-300P, S-300W and S-300F (the newest variants are designated S-400 and S-500) multi-role air and missile defence weapons systems. They all have some capabilities against ballistic missiles but it is very difficult to define it precisely. As the Russians treat their air defence, especially $S$ - 400 Triumph, as an important tool of political propaganda and information warfare, perceived as such. That is why its capabilities are on the one hand largely unconfirmed by independent sources and highly 'mythologized's6 on the other. From time to time the information on the other Russian systems, including new strategic ones appears, but their verification is also highly problematic.

Japan. This country is an important partner of the United States in the development of sea-based SM-3 system, including the newest SM-3 block IIA. It is already installed aboard four guided missile destroyers of the Kongō class and two more of the Atago class. Apart from this, the Japanese have sixteen batteries of Patriot PAC-3, which op-

55 In Russian: Воздушно-космические силы Вооружённых сил Российской Федерации, ВКС ВС России. The military branch that combines air force plus space force and air defence force under single command, established on December 1, 2011.

56 M. Dura, “Rosyjska 'prawda' o systemie S-400”, Defence24, 26 January 2017, at <http://www.defence24. pl/533952,rosyjska-prawda-o-systemie-s-400>, 27 January 2017. 
erate missiles manufactured by Mitsubishi. ${ }^{57}$ Japan also mulls further enhancement of its missile defence by purchasing American-made THAAD or preferably Aegis Ashore systems. ${ }^{58}$ Missile defence sensor network is also well developed and it is highly integrated with American missile defence infrastructure on the Asiatic theatre. From the point of view of Japan the most immediate missile threat is of course North Korea with its increasingly capable missile arsenal, but the threat from China is also taken into the consideration.

India. Delhi is working on the development of missile defence since the half of $1980 \mathrm{~s}^{59}$ and currently a composite, two-layered system is being fielded. The first layer is PAD $-1,{ }^{60}$ the weapons system that has been developed with the components acquired from Israel and from some other countries. It is adjusted to intercept ballistic missiles that have the range of $200-2000 \mathrm{~km}$ within the $80 \mathrm{~km}$ operational ceiling ${ }^{61}$ and at the distances $150-200 \mathrm{~km}^{6}{ }^{6}$ The lower layer of the Indian missile defence is the newly designed, point-defence weapons system $\mathrm{AAD}^{63}$ that is supposed to intercept targets at the distance of $30 \mathrm{~km}$ and up to the ceiling of $30 \mathrm{~km} .{ }^{64}$ Basically it is an air defence system, the anti-ballistic capability is only one of its functions. According to the current plans missile defence is to cover Mumbai area in the first place and the region surrounding New Delhi later on. ${ }^{65}$ The establishment of Indian missile defence may undoubtedly affect regional stability, taking into account the abovementioned role of missile arsenal in the security strategy of Pakistan - it is very likely that it could speed up the regional strategic arms race.

China. The Chinese military is highly secretive, that is why not much of detailed information is available with regard to missile defence. However, it is well known that this country has imported Russian S-300 systems and copied them domestically, probably with some upgrades. Thus, there are original S-300PMs, S-300PMUs, S-300Fs and

57 S.M. Pekkanen, “Japan's Ballistic Missile Defense and 'Proactive Pacifism”, in C.M. Kelleher, P. Dombrowski (eds.), Regional Missile Defense..., pp. 207-218.

58 B. Perrett, “Tokyo Seeks New Ways to Stop North Korean Ballistic Missiles", Aviation Week \& Space Technologies, 19 May 2017, at <http://aviationweek.com/aviation-week-space-technology/tokyoseeks-new-ways-stop-north-korean-ballistic-missiles>, 19 May 2017.

59 "Powtórna oferta USA dla Indii", Altair. Agencja Lotnicza, 26 July 2012, at <http://www.altair.com. $\mathrm{pl} /$ news $/$ view?news_id=8233\&q=Powt\%C3\%B3rna\%20oferta\%20USA\%20dla\%20Indii $>$, 27 July 2012.

60 Prithvi Air Defence.

${ }_{61}$ “DRDO Ballistic Missile Defence System, India”, Army Technology, 2012, at <http://www.armytechnology.com/projects/drdo-bmd/>, 11 March 2013.

62 P. Topychkanov, India's Prospects in the Area of Ballistic Missile Defense. A Regional Security Perspective, Carnegie Endowment for International Peace, Carnegie Moscow Center Working Papers, 3, Moscow 2012, p. 21.

63 "Kolejne testy Akash", Altair. Agencja Lotnicza, 14 April 2016, at <http://www.altair.com.pl/news/ view?news_id=19175>, 16 April 2016.

64 P. Topychkanov, India's..., p. 21.

65 A.C. Winner, "Ballistic Missile Defense in South Asia", in C.M. Kelleher, P. Dombrowski (eds.), Regional Missile Defense..., p. 186. 
indigenous HQ-9s in service, however, the combat capabilities of the latter are probably lesser than of the original. ${ }^{66}$ China also conducted two test of midcourse missile defence, ${ }^{67}$ but there is no detailed information on that fact. It is widely thought that currently China is intensely pondering on the role of its own missile defence in the security strategy but there is still no precise and comprehensive understanding on this matter. ${ }^{68}$ One of important doctrinal conundrums that China currently has to solve is to how to reconcile its long standing and adamant objection with regard to development of the American missile defence, considered a threat to the strategic deterrent of China and thus highly destabilizing, with its possible own enlarged and evolved, dedicated missile defence.

Others. Basically we may divide other users of missile defence weapons systems into the two camps: one that uses the American systems and the second that operates Russian ones. Apart from already mentioned countries, the following Middle Eastern countries belong to the category: Egypt, Jordan, Kuwait, Bahrain, Saudi Arabia and United Arab Emirates and in the Far East Korea and Taiwan. All of them operate Patriot PAC-3 air and missile defence systems. Moreover, the UAE have ordered two upper tier batteries of the THAAD weapons system to become the first export user of this highly sophisticated, dedicated anti-missile system. Qatar is also about to introduce its missile defence based on the PAC-3 and THAAD systems.

It is worth noting that Saudi and Emirati missile defence is in constant combat situation, routinely conducting intercepts of ballistic missiles. In the course of the international military intervention in Yemen, that started in April 2015 and is led by Saudi Arabia, the rebel Houthi forces regularly fire ballistic missiles against Saudi targets. This are mainly Scud family obsolete SRBMs, but there is also the information that more sophisticated Russian made Tochka missile was also used. Since the start of the operation until May $19^{\text {th }}, 2017$ as many as 44 ballistic missiles were shot down and 13 more reached their targets in Saudi Arabia and UAE. ${ }^{69}$ This data does not however give the picture of the combat effectiveness of missile defence assets deployed in Saudi Arabia, because, firstly, the defence does not cover whole area of the country and secondly, these are mostly the official Saudi communiqués, which are routinely denied by Houthis. But even if unconfirmed in detail, there is a missile war on the Saudi Arabia's and UAE's borders.

Russian systems of the S-300P family are in the service in Armenia, Belarus, Ukraine, Slovakia, Venezuela, Azerbaijan, Bulgaria, Iran, Kazakhstan, Syria, Vietnam

66 T. Szulc, "S-300 i Buk po kantońsku, czyli chińskie wariacje na temat rosyjskich systemów przeciwlotniczych”, Nowa Technika Wojskowa, no. 11 (2012), pp. 18-29.

67 T. Farnsworth, "China Conducts Missile Defense Test", Arms Control Association, March 2013, at <http://www.armscontrol.org/act/2013_03/China-Conducts-Missile-Defense-Test>, 30 March 2013.

68 Ch.P. Twomey, M.S. Chase, “Chinese Attitudes Toward Missile Defense”, in C.M. Kelleher, P. Dombrowski (eds.), Regional Missile Defense..., pp. 207-210.

69 The source of all the data: "The Missile War in Yemen", Missile Threat - CSIS Missile Defense Project, 23 October 2016, at <https://missilethreat.csis.org/missile-war-yemen/>, 9 November 2017. 
and Greece (they were bought by Cyprus but transferred to Greece in order not to destabilize the situation on the divided island).

\section{MISSILE DEFENCE OF THE USA}

The United States consider missile defence to be one of the most important tools of their security strategy - there are many reasons for that and it is elaborated in detail in one of the following articles. ${ }^{70}$ That is why the United States fields the most sophisticated, the most advanced and the biggest missile defence system in the world. Elements of the American missile defence are also part of NATO effort and significant portion of the military installations of that program are going to be located in Poland, thus influencing Polish security policy. These are the reasons why it seems proper to devote a whole chapter of this paper to describe the Ballistic Missile Defence System (BMDS) that has been created by the USA. This would complete the task of our work as an introduction to the four-part set of texts concerning missile defence in the context of the security of Poland.

All American effort related to missile defence is coordinated by Missile Defence Agency that controls the research and development, testing and acquisition of the assets that are subsequently handed to the combat units. On the other hand, the actual use of missile defence is coordinated by the regional Combatant Commands and the US Strategic Command, but the certain combat units are within the structure of the US Army and US Navy. Missile defence assets are liked into the Command and Control, Battle Management, and Communications (C2BMC) structure as the integrating element of the BMDS. It provides situational awareness by turning detailed data into decision quality information for combatant commanders,${ }^{71}$ as well as it depicts he status of the overall BMDS from the president down to the operational levels of command. ${ }^{72} \mathrm{It}$ also provides battle management capability that acts as a force multiplier to achieve integrated, layered ballistic missile defense through improved sensor resource management and engagement coordination. It is also responsible for secure network communications for the individual sensors and weapon elements of the BMDS. ${ }^{73}$

In short, BMDS may be defined as global, mostly road-, sea- and air-mobile, modular missile defence system, based on open, network-centric architecture. ${ }^{74}$ There are four weapons systems that are the effectors of the BMDS, together with the number of sensor arrays and supporting elements.

\footnotetext{
70 See T. Pugacewicz's article in this issue.

71 "Command and Control, Battle Management, and Communications (C2BMC)", Missile Defense Agency, 2017, at <https://www.mda.mil/system/c2bmc.html>, 23 April 2017.

72 Ibid.

73 Ibid.

74 For more information, see M. Czajkowski, Obrona..., pp. 262-282.
} 
The top layer of the US missile defence is the Ground-Based Midcourse Defense (GMD) that is responsible for the defence of the territory of the United States with the use of the Ground Based Interceptors (GBI) based in California and Alaska. The GBIs began to be fielded in 2005, to reach planned number of 30 in 2010. According to the decision of March 2013, next 14 interceptors are supposed to be added till the end of 2017. Actually there are 36 of GBIs installed in their silos which remain in operational readiness. ${ }^{75}$ It is worth noting that although combat ready, the system has been field tested against the target equivalent to the ICBM's warhead for the first time in May 30, $2017 .{ }^{76}$ It has never been tested in the salvo mode, although the doctrine has probably foreseen the deployment of multiple, perhaps even four of them against the single target $^{77}$ - such a test is currently scheduled for the summer $2018 .{ }^{78}$ It means that the whole GBI program is largely delayed ${ }^{79}$ and this makes the effectiveness of missile defence of the US soil be at least questionable.

The second missile defence weapons system it is mostly sea-based Aegis Ballistic Missile Defense (Aegis BMD) that is installed on the US Navy guided missile cruisers and guided missile destroyers. Its core comprises of the family of the Standard Missile (SM) interceptors, AN/SPY-1 air defence radar and Aegis battle management system. There are many variants of all those elements that define the actual combat capability of the given platform, most notable of them are the variety of missiles in use. SM-2 block IVA and just being introduced as a replacement to SM- 6 are dual use anti-aircraft and anti-ballistic weapon designed to defeat SRBMs and to a limited scope MRBMs in the terminal phase of their flight in the lower layers of the atmosphere. Note that the firing ranges of the missiles are commonly quoted in the sources as 200 and $400 \mathrm{~km}$ respectively, but that refers to their capabilities against air-breathing targets - the same parameter concerning incoming ballistic missiles is substantially smaller and varies in accordance to the target missile's actual velocity. This may change only if the capability to engage-on-remote is widely implemented. The upper tier of the Aegis BMD is SM-3 that also exists it two variants - block IA and block IB. Both are designed to exoatmospheric intercept of the SRBMs and MRBMs, with the limited capacity to engage IRBMs. The distance of the intercept is usually quoted as $500 \mathrm{~km}$ and the ceiling 160 $\mathrm{km} .{ }^{80}$ Aegis BMD is currently installed on 33 US warships, 5 of them are Ticonderoga

75 “Ground-based Midcourse Defense (GMD)", Missile Defense Agency, 2017, at <https://www.mda. mil/system/gmd.html>, 23 April 2017.

76 "Homeland Missile Defense System Successfully Intercepts ICBM Target", Missile Defense Agency, 30 May 2017, at <https://www.mda.mil/news/17news0003.html>, 1 June 2017.

77 G.N. Lewis, “Technical Controversy...”, p. 80.

78 Idem, "Delays in Planned GMD Tests", mostlymissiledefense, 7 June 2017, at <https://mostlymissile defense.com/2017/06/07/delays-in-planned-gmd-tests-june-7-2017/>, 10 June 2017.

79 Idem, “Could FTG-15 Delays Prevent the Deployment of 44 GBIs by the End of 2017?", mostlymissiledefense, 2 February 2017, at <https://mostlymissiledefense.com/2017/02/02/could-ftg-15-delaysprevent-the-deployment-of-44-gbis-by-the-end-of-2017-february-2-2017/>, 6 February 2017.

80 "RIM-161", Designation-Systems.Net, 2009, at <http://www.designation-systems.net/dusrm/m-161. html>, 23 April 2017. 
class cruisers and 28 are Arleigh Burke class destroyers. But a minimum number that would ensure that all operational needs are fulfilled is 40 ships, according to reliable assessments. ${ }^{81}$ As of 2014, there were 72 SM-2s missiles in stock, as of May 2015180 SM- $6 s^{82}$ were procured and the number of SM-3s, according to budgetary assumption, should reach 85 SM-3 block I/IA missiles and 128 SM-3 block IB at the end of 2017 fiscal year. ${ }^{83}$

Terminal High Altitude Area Defense (THAAD) is a road-mobile missile defence system designed to intercept SRBMs, MRBMs and IRBMs in highest layers of the atmosphere and well beyond, as it is basically an exoatmospheric hit-to-kill weapon. It is generally agreed among the experts that this system's range is about $200 \mathrm{~km}$ and the operational ceiling is about $150 \mathrm{~km} .{ }^{84}$ There are 6 fire units (batteries) of THAAD ${ }^{85}$ currently in service, each of them equipped with 6 launchers that are loaded with total 48 missiles.

Over fifty batteries of the Patriot PAC-3 air defence system form the lowest layer of the US missile defence. It has already been mentioned above and described in some detail, as it is well known and fairly common weapon.

The BMDS also consists of a wide network of ground based, space-borne and even sea-borne sensors that are designed to detect, track, discriminate and target ballistic missiles. The first of the space systems that works for missile defence is the Defence Support Program that has been deployed as early as in 1970. Subsequent generations of satellites located in the geosynchronous orbits use infrared sensors designed to detect missile launches and provide the information on the location of such events. The second satellite system consisting of two vehicles in the $1350 \mathrm{~km}$ orbit, designed especially for the BMDS, is the Space Tracking and Surveillance System (STSS). It not only detects the launches missiles, but also tracks their trajectories in the mid-course phase of the flight providing preliminary acquisition and the targeting data for the ground sensors, however the latter feature is still in the development stage. In 2017 an experimental program named the Spacebased Kill Assessment (SKA), a network of small sensors hosted on commercial satellites, is scheduled to be initiated. It is tasked to support the defence system by providing real-time information on the effectiveness of the intercepts. The spaceborne component of the BMDS sensor network is being operated by the US Air Force.

Ground based tracking systems are first of all the huge stationary early warning radars that were erected during the Cold War and have been updated to serve with the

81 According to US Navy estimates, in: R. O'Rourke, Navy Aegis Ballistic Missile Defense (BMD) Program. Background and Issues for Congress, Congressional Research Service, Washington, 25 October 2016, p. 14.

82 “Standard Missile-6 (SM-6)", Missile Threat - CSIS Missile Defense Project, 14 April 2016, at <https:// missilethreat.csis.org/defsys/sm-6/>, 23 April 2017.

83 R. O'Rourke, Navy..., p. 7.

84 “THAAD", in Encyclopedia Astronautica, 2016, at <http://www.astronautix.com/t/thaad.html>, 26 April 2017.

85 “Terminal High Altitude Area Defense (THAAD)", Missile Defense Agency, at <https://www.mda. $\mathrm{mil} /$ system/thaad.html>, 21 January 2017. 
BMDS. They are located in California, Great Britain, Greenland, Alaska and on the Aleutian Islands and are operated by the US Air Force. Additionally there are five roadmobile, air-transportable radar stations AN/TPY-1 (the same that serve as fire control units for the THAAD system), used as the forward based warning and tracking systems. ${ }^{86}$ There is also a unique sea-borne platform, Sea-Based X-Band Radar (SBX) that is mounted on the huge (totalling 50000 tonnes of the displacement when ballasted ${ }^{87}$ ) floating, self-propelled platform, especially dedicated to co-operate with the GMD. It is providing detection, tracking and discrimination data for the defence of the US territory - as a rule it is supposed to be stationed somewhere in the North Pacific, along the axis of the Korean missile threat.

BMDS is, as it was already mentioned, a global effort, especially because almost all of its elements are transportable and may be concentrated in selected areas worldwide. Currently it is deployed in three operational theatres, against two officially stated threats. It means that there are three areas that are supposed to be defended by the assets that are deployed there and that remain in active combat duty. Missile defence on the given theatre may of course be augmented if needed.

The first area of deployment of the BMDS is Europe, where USA have conducted the EPAA since 2009 and the program in its current shape is about to come to the completion in the coming year or two. It was supposed to subsequently deploy more and more capable systems destined to defend the territories of the European allies of the USA against the long range attack from Iran, or more generally, from the Middle East. Currently there are four ${ }^{88}$ guided missile destroyers equipped with the Aegis BMD system and SM-2/SM-3/SM-6 interceptors based in Rota, Spain, according to the special agreement with this country. The main task of this force is to provide anti-missile patrols across the south European waters with at least two vessels at the time. The second element of the EPAA is ground based variant of ship-borne SM-3/Aegis system, called Aegis Ashore - there are two bases supposed to be equipped with this system. One located in Deveselu, Romania was operationally certified on May $2016^{89}$ and holds the 24-cell launcher with SM-3 block IB missiles. The second one is the base in Redzikowo, northern Poland. Its construction started in 2016 and should be finished in 2018, although there are some doubts with regard to that, connected with the possible shift in American approach to missile defence. ${ }^{90}$ If completed, this base should be equipped

86 "Army Navy / Transportable Radar Surveillance (AN/TPY-2)", Missile Defense Agency, 28 July 2016, at <https://www.mda.mil/global/documents/pdf/an_tpy2.pdf>, 17 February 2017.

87 “Sea-Based X-Band Radar", Missile Defense Agency, 28 July 2016, at <https://www.mda.mil/global/ documents/pdf/sbx.pdf>, 25 April 2017.

88 Ross (DDG-71), Donald Cook (DDG-74), Carney (DDG-64) and Porter (DDG-78).

89 “Aegis Ashore Missile Defense System-Romania Operationally Certified", America’s Navy, Story Number: NNS160512-11, 12 May 2016, at <http://www.navy.mil/submit/display.asp?story_id=94662>, 26 January 2017.

90 “Redzikowo w grze o nową bazę antyrakietową w USA?", Altair. Agencja Lotnicza, 9 February 2017, at <http://www.altair.com.pl/news/view?news_id=21567>, 9 February 2017. 
with new, much more capable SM-3 block IIA interceptors that have just recently begun the testing procedure. ${ }^{91}$

The second area of deployment of BMDS assets is the Persian Gulf. It is somehow connected with the European theatre but there is very important local context of missile defence deployment there. American partners such as Gulf States and the most notably Israel are constantly threatened by a growing missile threat from Iran. The Jewish state, apart from its own capabilities, hosts one AN/TPY-1 radar station operating in the surveillance mode, called Forward Based X-Band Radar (FBX). The second is located in Turkey, the third in Qatar. There are also US interceptors deployed in the Persian Gulf area: the Gulf and the ocean nearby is patrolled by the two or three Aegis BMD vessels and eight Patriot PAC-3 batteries are located in Bahrain, Kuwait, Qatar and UAE. ${ }^{22}$

The third main area of deployment of the US missile defence is the region of the north eastern Asia, where a good portion of the BMDS assets is stationed. First of all, there is the GMD component in Alaska and California with the SBX radar station in forward position. The other assets are 7 Aegis BMD ships stationed in Japan, US Army Patriot batteries in South Korea and in some bases throughout the region. Additionally, Guam is protected by the THAAD battery, the other one started to be deployed to the location just west of the city Daegu in South Korea on March 7, 201793 - it was supposed to reach operational status later that year. ${ }^{94}$ Officially all those systems are supposed to defend Korea, Japan, American forces and the US territory against missile launches from North Korea, but it is rather obvious that at least part of this potential is directed to counter Chinese threat. It has been already mentioned that China is constantly augmenting A2/AD capabilities and the United States attempt to counter these developments in order to ensure operational freedom of action of their armed forces. The US consider anti-access strategies as a huge impediment to its overall foreign policy, as it is to great extend backed by military might which is the symbol and the instrument of the American presence and engagement. In this context missile defence seems to be one of the most important necessities.

Further development of the BMDS is supposed to follow two directions. One is the

91 The first intercept took place on February 3, 2017 - it was the third flight test of the missile, see "U.S., Japan Successfully Conduct First SM-3 Block IIA Intercept Test”, Missile Defense Agency, 3 February 2017, at <https://www.mda.mil/news/17news0002.html>, 6 February 2017.

92 M. Elleman, W. Alsayed, “Ballistic...”, pp. 175-176.

93 "Pacom Deploys Defensive Anti-Missile System to Korean Peninsula”, US Department of Defense, 7 March 2017, at <https://www.defense.gov/News/Article/Article/1104428/pacom-deploysdefensive-anti-missile-system-to-korean-peninsula/>, 26 April 2017.

94 According to the Pentagon Spokesman the battery reached initial operational capability by the end of April 2017, but credibility of this information is questionable, minding the overall political situation within the US and in the current relations between Korea and the United States. See M. Ryan, "Controversial Missile Defense Shield Operational in South Korea", The Washington Post, 1 May 2017, at <https://www.washingtonpost.com/news/checkpoint/wp/2017/05/01/controversialmissile-defense-shield-operational-in-south-korea/?hpid=hp_hp-more-top-stories_cp-thaad950pm\%3Ahomepage\%2Fstory\&utm_term=.6038b1b0abea>, 2 May 2017. 
obvious increase of the stockpile of interceptors and the number of launchers, as a antimissile arsenal should quantitatively match the threat. The second, much more important course of missile defence evolution is the enhancement of combat effectiveness. It is no easy task, especially because the quality of the threat also evolves, as it has been mentioned before. The BMDS is then constantly enhanced to be able to defend against more and more complex targets. There is for example information that the SM- 6 test conducted in December 2016 involved the intercept of a target missile that simulated the flight of the warhead of the Chinese MRBM DF-21D, ${ }^{95}$ which is designed to attack large warships and usually referred to as a carrier-killer. This information is unconfirmed however, as the official statement by the MDA is quite general, as usual..${ }^{96} \mathrm{Of}$ course, the testing program is surely more and more advanced and it refers to more and more complex situations. Especially the methods of coordination of detection, tracking and targeting of various sensor and launch platforms, known as launch-on-remote and engage-on-remote are currently field tested. Thus, the BMDS is in constant development and modernization process which is its strength and the weakness at the same time. It is for example commonly noticed that newly fielded variants of weapons are usually not fully tested and sometimes must be upgraded immediately after entering service, ${ }^{97}$ which makes the defences somehow unreliable. What is more, some expert observers point out that flight tests of the interceptor missiles are carefully scripted and still inadequate in many instances. For example, the abovementioned intercept test of the GBI has involved, according to the MDA director, the threat-representative ICBM target $\left[\ldots . . . .^{98}\right.$ However, a noted specialist calculated that in fact it represented a missile of the range around 5800 $\mathrm{km} .{ }^{99}$ True, it is ICBM by the classification, but such a missile would not be able to reach the American soil if launched from North Korea. Thus the question of real combat value of certain system persists even within the US government agencies, ${ }^{100}$ along with more general critique that refers to the intrinsic difficulties of missile defence, discussed above.

Finally it should be reiterated that missile defence is an increasingly important ele-

95 “'Fireball' - We're Taking It, We're Taking It, We're Taking It Down”, Missile Defence Advocacy Alliance, 15 December 2016, at <http://missiledefenseadvocacy.org/alert/fireball-were-taking-it-weretaking-it-were-taking-it-down/>, 10 January 2017.

96 "MDA Conducts SM-6 MRBM Intercept Test", Missile Defense Agency, 14 December 2016, at <https://www.mda.mil/news/16news0012.html>, 10 January 2017.

97 "Opportunity Exists to Strengthen Acquisitions by Reducing Concurrency", GAO-12-486, US Government Accountability Office, April 2012, at <http://www.gao.gov/assets/600/590277.pdf>, 4 January 2013.

98 The quotation from: J. Judson, "Missile Takedown: Historic ICBM Intercept Test Sends Strong Message to North Korea”, Defence News, 30 May 2017, at <http://www.defensenews.com/articles/directcollision-for-us-homeland-missile-defense-interceptor-test-against-icbm-target>, 1 June 2017.

99 L. Grego, "What You Should Know about the Upcoming GMD Missile Defense Test: Part 1", (Blog) All Things Nuclear, Union of Concerned Scientists, 29 May 2017, at <http://allthingsnuclear.org/ lgrego/2017-gmd-test-part-1\#.WSzW-F13miM.twitter>, 6 June 2017.

100 "Some Progress Delivering Capabilities, but Challenges with Testing Transparency and Requirements Development Need to Be Addressed", US Government Accountability Office, May 2017, at <https:// www.gao.gov/assets/690/684961.pdf>, 5 June 2017. 
ment of the US security strategy and foreign policy and it will remain so. That is why it will be developed in the future, probably with even more and more emphasis. Today its role is predominantly political, as it is an instrument of deterrence oriented against the weaker actors that consider ballistic missiles to be an asymmetric tool counterbalancing American military advantage. The second task of the US missile defence is to support the effort to maintain global operational freedom of the US armed forces. This refers especially to the Pacific theatre and places BMDS as one of the main military instruments used to oppose the enlarging and modernizing military potential of China.

As we are now in the transition period of the new administration reviewing the strategies and policies of the United States it is worth noting that the doctrinal and financial shape of the future missile defence is not entirely determined. This especially refers to the European element of the BMDS in the context of still vague US policy towards Russia which has staunchly opposed the American effort to date. ${ }^{101}$ On the other hand it seems that in general terms the presidential apprehension towards missile defence is secure, especially when it comes to the defence of the US soil. ${ }^{102}$ Many of the uncertainties will probably be clarified with the Missile Defence Review that is scheduled to be published by the end of 2017 and will surely encompass the new vision. ${ }^{103}$ It has been ordered by the Congress even before the presidential election and is enclosed in the Defense Authorization Act for FY 2017, passed through Senate on April 18, 2016. The DAE states that the effort regarding missile defence should encompass the measures to defeat missiles prior to launch, defensive means against cruise missiles and hypersonic glide weapons. ${ }^{104}$ So it is calling for focused action on defence against modern weapons that might contest American military superiority both in the global perspective and in the local scale. The same act also calls for the commencement of studies that could eventually lead to the construction of space-based anti-missile weapons. ${ }^{105}$ The last provision, if implemented, could pose a revolutionary change in the American position on missile defence. Additionally, according to the presidential memorandum, the new MDR is supposed to: to identify ways of strengthening missile-defense capabilities, rebalancing homeland and theatre defense priorities [...]. ${ }^{106}$ The latter provision sug-

101 R. Oswald, “Trump's Plans for European Missile Defense a Mystery”, The Bulletin of Atomic Scientists, 7 December 2016, at <http://thebulletin.org/trump\%E2\%80\%99s-plans-european-missile-defensemystery10258>, 7 January 2017.

102 D. Wasserbly, “Missile Defences a Top Priority for Trump”, IHS Jane’s 360, 23 January, 2017, at <http:// www.janes.com/article/67141/missile-defences-a-top-priority-for-trump>, 6 February 2017.

103 Idem, “Trump, Mattis Begin Shaping Pentagon Programmes”, IHS Jane’s 360, 1 February 2017, at <http://www.janes.com/article/67372/trump-mattis-begin-shaping-pentagon-programmes >, 6 February 2017.

104 "H.R.4909 - National Defense Authorization Act for Fiscal Year 2017 - 114 ${ }^{\text {th }}$ Congress (2015-2016). Passed House amended (05/18/2016)", US Congress, 2016, sections 1652, 1657, at <https://www. congress.gov/bill/114th-congress/house-bill/4909>, 26 April 2017.

105 Ibid., section 1656.

106 "Presidential Memorandum on Rebuilding the U.S. Armed Forces", The White House, Office of the Press Secretary, 27 January 2017, at <https://www.whitehouse.gov/the-press-office/2017/01/27/ presidential-memorandum-rebuilding-us-armed-forces $>, 6$ February 2017. 
gests possible changes of the current missile defence philosophy which is somehow leaning to favor the regional defence in expense of the defence of the US territory.

\section{CONCLUSIONS}

First of all it should be reiterated that the picture of missile defence in the public discourse is usually skewed by mythological attitude and wishful thinking with regard to its effectiveness - this observation refers not only to Poland. Of course, missile defence may find its place in the military policy and security strategy of every country, but the expectations concerning its effectiveness are usually highly excessive - and that certainly complicates every debate on the subject. In other words, it is commonly believed, that because there are such weapon systems that are called anti-missile it means that they are generally effective within their anti-missile task. It is also usually omitted that all the systems that are currently fielded, together with the ones under the development, are designed to counter only certain threats in certain situations and it is usually not possible to move them into another tactical and strategic environment.

Missile defence is therefore an important element of defence strategies as well as of the foreign policies of many countries, especially of Israel and the United States. But its role is strictly defined within the framework of certain technological, organizational and politico-strategic realities. Of course, its significance increases as the missile threat increases quantitatively and qualitatively, but nevertheless, missile defence is still in relatively early stages of the development and its effectiveness as the weapon is still in question.

Let us illustrate the problem. As of today the only missile defence system that has been comprehensively battle proven is Israeli Iron Dome. But note that it was designed specifically to defeat artillery rocket systems, as described above. But what would its effectiveness be against the same quantity of missiles equipped with the simplest guidance system? Firstly, there would be three to four times more of them to intercept, and secondly they would be maneuvering, thus being much more difficult to intercept. It is rather obvious that anti-Israeli militants will do whatever it takes to obtain guided missiles to restore the usefulness of their missile force as the strategic weapon of terror. In fact there are indications that at least some quantity of guided weapons is already in the possession of the militants, ${ }^{107}$ more would likely follow. No one can predict now if Iron Dome will remain effective enough in such conditions or it would be saturated and defeated. This way, serious doubts regarding the effectiveness of the system persist, even though it is the best proven system.

Similarly, American systems, despite the constant enhancement of the methods of foiling the penetration capabilities of modern ballistic missiles, have still not been battle-tested against the most modern of that kind. Patriot PAC-3 used several times in

107 A. Harel, "Israel's New Missile Defense System Is a Clear Message to Iran, but It Isn't Perfect", Haaretz, 3 April 2017, at <http://www.haaretz.com/israel-news/.premium-1.781028>, 26 April 2017. 
Iraq in 2003 and currently fighting the Houthi insurgency missile attacks against Saudi Arabia has been confronted only with rather primitive missile designs.

Save those two very specific instances we can parse the effectiveness of the weapons fielded or being developed only according to their test's results. But by their nature tests are only supposed to confirm simulations in a controlled environment that is profoundly different from real battlefield. In fact, the testing, however realistic it would be, can allow assessing only the reliability of certain technologies, but when it comes to operational effectiveness, only the actual use of the given weapon in the battlefield, with all its complexity and uncertainty, can tell. ${ }^{108}$

If there are some more reassuring indications concerning the effectiveness of missile defence, they are few and must not be taken at face value. Thus, if the information, that Saudi Patriots brought down soviet-made Tochka missile confirms it would surely mean some advance, because it is a more demanding target than the obsolete Scud, or something else of the sort. But still, if rebels were able to use missile's full potential, it is uncertain. The same goes for the downing of the target mocking the DF-21D's warhead by the American SM-6 - if this is true it would be an important step forward, but this information is not confirmed. Probably the best news for missile defence is that Israel is apparently working on the design of the laser-beam variant of the Iron Dome. Should it materialize it would offset the coming rise of quality of the anti-Israel militant's arsenal. From the wider perspective, it would also be the beginning of the expected breakthrough in missile defence principles, but it is still unsure right now.

Finally, it should be underlined that according to American doctrine and declared role of the BMDS, it is supposed to fight only the quantitatively and qualitatively limited missile threat. On the other hand, it is an important part of the strategy to counter anti-access technologies, which would in many instances mean much more demanding threat. But again, according the existing information this task has not been accomplished yet, and its completion is rather far away. What is more, the main opponents with respect to that are Chinese and Russians and they are not watching American progress idly but rather improve their missile technologies and tactics to offset possible US advances. In fact there is an arms race in progress, with all its uncertainties and possible surprises and with its inherent logic of expansion. One of the possible developments of such a race is weaponization of the outer space, as the US mulls the spaceborne leg of missile defence ${ }^{109}$ and the opponents develop anti-satellite weapons.

108 G.N. Lewis, “Technical Controversy...”, pp. 81-82.

109 See for example J. Drew, “North Korea's ICBM Test Renews Calls for Space-Based Kill Layer”, Aviation Week, 5 July 2017, at <http://aviationweek.com/defense/north-korea-s-icbm-test-renews-calls-spacebased-kill-layer $>, 6$ July 2017. 


\section{BIBLIOGRAPHY}

“Aegis Ashore Missile Defense System-Romania Operationally Certified”, America's Navy, Story Number: NNS160512-11, 12 May 2016, at <http://www.navy.mil/submit/display. asp?story_id=94662>.

“Army Navy / Transportable Radar Surveillance (AN/TPY-2)”, Missile Defense Agency, 28 July 2016, at <https://www.mda.mil/global/documents/pdf/an_tpy2.pdf>.

"Ballistic Missile", in DoD Dictionary, 2017, at < http://www.dtic.mil/doctrine/dod_dictionary/ data/b/2726.html>.

"Ballistic Missile", in Encyclopaedia Britannica, 2017, at <https://www.britannica.com/ technology/ballistic-missile>.

Barnard A., Schmitt E., "Hezbollah Moving Long-Range Missiles from Syria to Lebanon, an Analyst Says", New York Times, 2 January 2014, at <https://www.nytimes.com/2014/01/03/ world/middleeast/hezbollah-is-said-to-transfer-missiles.html?_r=0 $>$.

Baucom D.R., Origins of SDI 1944-1983, Lawrence, Kan. 1992.

Ben David A., "Iron Dome Blunts 90\% of Enemy Rockets", Aviation Week \& Space Technology, 1 September 2014, at <http://aviationweek.com/defense/iron-dome-blunts-90-enemyrockets $>$.

Berger Z., "Arrow (Israel)”, Missile Defence Advocacy Alliance, September 2016, at <http:// missiledefenseadvocacy.org/missile-defense-systems-2/allied-air-and-missile-defense-systems/ allied-intercept-systems-coming-soon/arrow-israel/>.

Binnie J., "Iran Successfully Tests Radar-Guided Anti-Ship Ballistic Missile”, IHS Jane’s 360, 10 March 2017, at <http://www.janes.com/article/68625/iran-successfully-tests-radarguided-anti-ship-ballistic-missile $>$.

Chayes A., Wiesner J.B. (eds.), ABM. An Evaluation of the Decision to Deploy Antiballistic Missile System, London 1970.

"Command and Control, Battle Management, and Communications (C2BMC)", Missile Defense Agency, 2017, at <https://www.mda.mil/system/c2bmc.html>.

“Commander: IRGC Will Destroy 35 US Bases in Region if Attacked”, Fars News Agency, 4 July 2012, at <http://english2.farsnews.com/newstext.php?nn=9103084990>.

Czajkowski M., "Korea Północna vs. BMDS”, in W. Sokała, B. Zapała (eds.), Asymetria i hybrydowość - stare armie wobec nowych konfliktów, Warszawa 2011.

Czajkowski M., “Obrona przeciwrakietowa Izraela”, in R. Kłosowicz, B. Szlachta, J.J. Węc (eds.), Dylematy strategiczne XXI wieku. Ksiegga Jubileuszowa dedykowana Profesorowi Michatowi Chorośnickiemu z okazji czterdziestolecia pracy naukowej, Kraków 2013.

Czajkowski M., Obrona przeciwrakietowa w stosunkach międzynarodowych, Kraków 2013.

“DRDO Ballistic Missile Defence System, India”, Army Technology, 2012, at <http://www. army-technology.com/projects/drdo-bmd/>.

Drew J., "North Korea's ICBM Test Renews Calls for Space-Based Kill Layer”, Aviation Week, 5 July 2017, at <http://aviationweek.com/defense/north-korea-s-icbm-test-renews-callsspace-based-kill-layer $>$.

Dura M., “Niemcy: Umowa na system MEADS w przyszłym roku?”, Defence24, 14 July 2016, at <http://www.defence24.pl/408446,niemcy-umowa-na-system-meads-w-przyszlym-roku>. 
Dura M., “Rosyjska 'prawda' o systemie S-400”, Defence24, 26 January 2017, at <http://www. defence24.pl/533952,rosyjska-prawda-o-systemie-s-400>.

Elleman M., Alsayed W., "Ballistic Missile Defense Cooperation in the Arabian Gulf”, in C.M. Kelleher, P. Dombrowski (eds.), Regional Missile Defense from a Global Perspective, Stanford 2015.

Farnsworth T., "China Conducts Missile Defense Test”, Arms Control Association, March 2013, at <http://www.armscontrol.org/act/2013_03/China-Conducts-Missile-Defense-Test>.

“'Fireball' - We're Taking It, We're Taking It, We're Taking It Down”, Missile Defence Advocacy Alliance, 15 December 2016, at <http://missiledefenseadvocacy.org/alert/fireball-weretaking-it-were-taking-it-were-taking-it-down/>.

Garwin R.L., Bethe H., “Anti-Ballistic-Missile Systems”, Scientific American, vol. 218, no. 3 (1968). Gera V., Heintz J., "Baltic Region Worried about Russian Missiles in Kaliningrad”, U.S. News, 8 October 2016, at <http://www.usnews.com/news/world/articles/2016-10-08/polandconcerned-about-russian-missiles-sent-to-kaliningrad $>$.

Grego L., "What You Should Know about the Upcoming GMD Missile Defense Test: Part 1", (Blog) All Things Nuclear, Union of Concerned Scientists, 29 May 2017, at <http:// allthingsnuclear.org/lgrego/2017-gmd-test-part-1\#.WSzW-F13miM.twitter>.

“Ground-based Midcourse Defense (GMD)", Missile Defense Agency, 2017, at <https://www. mda.mil/system/gmd.html>.

Haddick R., "This Is Not a Test”, Foreign Policy, 17 August 2012, at < http://www.foreignpolicy. com/articles/2012/08/17/this_is_not_a_test $>$.

Harel A., "Israel's New Missile Defense System Is a Clear Message to Iran, but It Isn't Perfect", Haaretz, 3 April 2017, at <http://www.haaretz.com/israel-news/.premium-1.781028>.

Harel A., Cohen G., Khoury J., "Israeli Air Force Strikes Targets in Syria; Assad Forces Threaten 'Direct' Retaliation”, Haaretz, 17 March 2017, at <http://www.haaretz.com/israelnews/1.777902>.

“Homeland Missile Defense System Successfully Intercepts ICBM Target”, Missile Defense Agency, 30 May 2017, at <https://www.mda.mil/news/17news0003.html>.

"H.R.4909 - National Defense Authorization Act for Fiscal Year $2017-114^{\text {th }}$ Congress (2015-2016). Passed House amended (05/18/2016)", US Congress, 2016, at <https://www. congress.gov/bill/114th-congress/house-bill/4909>.

"Israel: Any War with Hezbollah Will Be Devastating”, Al Jazeera, 20 April 2016, at <http:// www.aljazeera.com/news/2016/04/israel-war-hezbollah-devastating-160420183832190. html>.

Izewicz P., Iran's Ballistic Missile Programme. Its Status and the Way Forward, EU Non-Proliferation Papers, No. 57, SIPRI, Stockholm, April 2017.

Judson J., "Missile Takedown: Historic ICBM Intercept Test Sends Strong Message to North Korea”, Defence News, 30 May 2017, at <http://www.defensenews.com/articles/directcollision-for-us-homeland-missile-defense-interceptor-test-against-icbm-target $>$.

“Kolejne testy Akash”, Altair. Agencja Lotnicza, 14 April 2016, at <http://www.altair.com.pl/ news/view?news_id=19175>. 
Larrinaga N. de, “France Receives Last SAMP/T Air Defence System”, IHS Jame’s 360, 17 March 2016, at <http://www.janes.com/article/58841/france-receives-last-samp-t-air-defencesystem $>$.

Levite A., Brom S., "From Dream to Reality”, in C.M. Kelleher, P. Dombrowski (eds.), Regional Missile Defense from a Global Perspective, Stanford 2015.

Lewis G.N., "Could FTG-15 Delays Prevent the Deployment of 44 GBIs by the End of 2017 ?", mostlymissiledefense, 2 February 2017, at <https://mostlymissiledefense. com/2017/02/02/could-ftg-15-delays-prevent-the-deployment-of-44-gbis-by-the-end-of2017-february-2-2017/>.

Lewis G.N., "Delays in Planned GMD Tests”, mostlymissiledefense, 7 June 2017, at <https:// mostlymissiledefense.com/2017/06/07/delays-in-planned-gmd-tests-june-7-2017/>.

Lewis G.N., “Technical Controversy: Can Missile Defense Work?”, in C.M. Kelleher, P. Dombrowski (eds.), Regional Missile Defense from a Global Perspective, Stanford 2015.

Lewis J., “Kim Jong Un's Quest for an ICBM”, Foreign Affairs, 9 June 2017, at <https://www. foreignaffairs.com/articles/north-korea/2017-06-09/kim-jong-uns-quest-icbm?cid=intlea\&pgtype $=$ hpg $>$.

Lewis J., "Why Did Saudi Arabia Buy Chinese Missiles?", Foreign Policy, 30 January 2014, at <http://foreignpolicy.com/2014/01/30/why-did-saudi-arabia-buy-chinese-missiles/>.

Lindsay J.M., O'Hanlon M., Defending America. The Case for Limited National Missile Defense, Washington 2001.

Lokshin J., “David's Sling (Israel)”, Missile Defence Advocacy Alliance, August 2016, at <http:// missiledefenseadvocacy.org/missile-defense-systems-2/allied-air-and-missile-defense-systems/ allied-intercept-systems-coming-soon/davids-sling-israel/>.

Lokshin J., "Iron Dome (Israel)", Missile Defence Advocacy Alliance, August 2016, at <http:// missiledefenseadvocacy.org/missile-defense-systems-2/allied-air-and-missile-defense-systems/ allied-intercept-systems-coming-soon/iron-dome-israel/>.

“MDA Conducts SM-6 MRBM Intercept Test”, Missile Defense Agency, 14 December 2016, at <https://www.mda.mil/news/16news0012.html>.

"Missile", in Dictionary by Mirram-Webster, 2017, at <https://www.merriam-webster.com/ dictionary/missile>.

“The Missile War in Yemen”, Missile Threat - CSIS Missile Defense Project, 23 October 2016, at <https://missilethreat.csis.org/missile-war-yemen/>.

"New START Treaty Aggregate Numbers of Strategic Offensive Arms", Bureau of Arms Control, Verification, and Compliance, 1 April 2017, at <https://www.state.gov/t/avc/ newstart/269406.htm>.

Noris G., "Classified Report on Hypersonics Says U.S. Lacking Urgency”, Aviation Week \& Space Technology, 14 February 2017, at <http://aviationweek.com/defense/classified-reporthypersonics-says-us-lacking-urgency $>$.

Opall-Rome N., "Israeli Satellite Imagery Shows Russian Nuclear-Capable Missiles in Syria”, Defense News, 6 January 2017, at <http://www.defensenews.com/articles/israeli-satelliteimagary-shows-russian-nuclear-capable-missiles-in-syria $>$. 
“Opportunity Exists to Strengthen Acquisitions by Reducing Concurrency", GAO-12-486, US Government Accountability Office, April 2012, at <http://www.gao.gov/assets/600/590277. pdf $>$.

O’Rourke R., Navy Aegis Ballistic Missile Defense (BMD) Program. Background and Issues for Congress, Congressional Research Service, Washington, 25 October 2016.

Oswald R., "Trump's Plans for European Missile Defense a Mystery”, The Bulletin of Atomic Scientists, 7 December 2016, at <http://thebulletin.org/trump\%E2\%80\%99s-plans-europeanmissile-defense-mystery10258>.

“Pacom Deploys Defensive Anti-Missile System to Korean Peninsula”, US Department of Defense, 7 March 2017, at <https://www.defense.gov/News/Article/Article/1104428/pacomdeploys-defensive-anti-missile-system-to-korean-peninsula/ $>$.

"Patriot PAC-3", Military Today, 2017, at <http://www.military-today.com/missiles/patriot_ pac3.htm>.

Pekkanen S.M., “Japan’s Ballistic Missile Defense and 'Proactive Pacifism'”, in C.M. Kelleher, P. Dombrowski (eds.), Regional Missile Defense from a Global Perspective, Stanford 2015.

Perrett B., “Tokyo Seeks New Ways to Stop North Korean Ballistic Missiles”, Aviation Week \& Space Technologies, 19 May 2017, at <http://aviationweek.com/aviation-week-spacetechnology/tokyo-seeks-new-ways-stop-north-korean-ballistic-missiles $>$.

"Powtórna oferta USA dla Indii", Altair. Agencja Lotnicza, 26 July 2012, at <http://www.altair. com.pl/news/view?news_id=8233\&q=Powt\%C3\%B3rna\%20oferta\%20USA\%20dla\%20 Indii>.

"Presidential Memorandum on Rebuilding the U.S. Armed Forces", The White House, Office of the Press Secretary, 27 January 2017, at <https://www.whitehouse.gov/the-pressoffice/2017/01/27/presidential-memorandum-rebuilding-us-armed-forces $>$.

“Redzikowo w grze o nową bazę antyrakietową w USA?", Altair. Agencja Lotnicza, 9 February 2017, at <http://www.altair.com.pl/news/view?news_id=21567>.

“RIM-161", Designation-Systems.Net, 2009, at <http://www.designation-systems.net/ dusrm/m-161.html>.

Ryan M., "Controversial Missile Defense Shield Operational in South Korea”, The Washington Post, 1 May 2017, at <https://www.washingtonpost.com/news/checkpoint/wp/2017/05/01/ controversial-missile-defense-shield-operational-in-south-korea/?hpid=hp_hp-more-topstories_cp-thaad-950pm\%3Ahomepage\%2Fstory\&utm_term $=.6038 \mathrm{~b} 1 \mathrm{~b}$ abea $>$.

“Sea-Based X-Band Radar”, Missile Defense Agency, 28 July 2016, at <https://www.mda.mil/ global/documents/pdf/sbx.pdf>.

Sessler A.M. et al., Countermeasures. A Technical Evaluation of the Operational Effectiveness of the Planned US National Missile Defense System, Union of Concerned Scientists, Cambridge, Mass. 2000, at <https://drum.lib.umd.edu/bitstream/handle/1903/4333/2000-UCS-CM. pdf ? sequence $=1 \&$ is Allowed $=y>$.

Shiriyev Z., "Azerbaijan's Possible Reactions to Armenia's Iskanders: Defense Versus Offense”, Eurasia Daily Monitor, vol. 13, no. 160 (5 October 2016), at <https://jamestown.org/program/ azerbaijans-possible-reactions-armenias-iskanders-defense-versus-offense/\#sthash.fsQvtrgA. dpuf>. 
"Some Progress Delivering Capabilities, but Challenges with Testing Transparency and Requirements Development Need to Be Addressed", US Government Accountability Office, May 2017, at <https://www.gao.gov/assets/690/684961.pdf>.

“Standard Missile-6 (SM-6)", Missile Threat - CSIS Missile Defense Project, 14 April 2016, at $<$ https://missilethreat.csis.org/defsys/sm-6/>.

Syring J.D., Ballistic Missile Defense Overiew, Missile Defense Agency, 14 August 2013, at <https://pl.scribd.com/document/176023320/Ballistic-Missile-Defence-Overview>.

Szulc T., "S-300 i Buk po kantońsku, czyli chińskie wariacje na temat rosyjskich systemów przeciwlotniczych”, Nowa Technika Wojskowa, no. 11 (2012).

“Terminal High Altitude Area Defense (THAAD)”, Missile Defense Agency, at < https://www. mda.mil/system/thaad.html>.

“THAAD”, in Encyclopedia Astronautica, 2016, at < http://www.astronautix.com/t/thaad.html>. Thaliyakkatti S., Chinese Perceptions on India's Long Range Missile Development: How Credible is India's Deterrence against China?, ISAS Working Paper, no. 258, 24 April 2017, Institute of South Asian Studies, National University of Singapore, at <https://www.isas.nus. edu.sg/ISAS\%20Reports/ISAS\%20Working\%20Papers\%20No.\%20258-Chinese\%20 Perceptions\%20on\%20India's\%20Long\%20Range\%20Missile\%20Development.pdf>.

Topychkanov P., India's Prospects in the Area of Ballistic Missile Defense. A Regional Security Perspective, Carnegie Endowment for International Peace, Carnegie Moscow Center Working Papers, 3, Moscow 2012.

Twomey Ch.P., Chase M.S., "Chinese Attitudes Toward Missile Defense”, in C.M. Kelleher, P. Dombrowski (eds.), Regional Missile Defense from a Global Perspective, Stanford 2015.

“U.S., Japan Successfully Conduct First SM-3 Block IIA Intercept Test”, Missile Defense Agency, 3 February 2017, at <https://www.mda.mil/news/17news0002.html>.

Wasserbly D., "Missile Defences a Top Priority for Trump”, IHS Jane’s 360, 23 January, 2017, at <http://www.janes.com/article/67141/missile-defences-a-top-priority-for-trump>.

Wasserbly D., “Trump, Mattis Begin Shaping Pentagon Programmes”, IHS Jane's 360, 1 February 2017, at <http://www.janes.com/article/67372/trump-mattis-begin-shaping-pentagonprogrammes $>$.

Williams I., Karako T., “North Korea's New Missiles on Parade”, Center for Strategic \& International Studies, 18 April 2017, at <https://www.csis.org/analysis/north-koreas-new-missilesparade>.

Winner A.C., "Ballistic Missile Defense in South Asia", in C.M. Kelleher, P. Dombrowski (eds.), Regional Missile Defense from a Global Perspective, Stanford 2015.

Wright D., "North Korea Appears to Launch Missile with 6,700 km Range”, (Blog) All Things Nuclear, Union of Concerned Scientists, 3 July 2017, at <http://allthingsnuclear.org/ dwright/north-korea-appears-to-launch-missile-with-6700-km-range >.

Marek CZAJKOWSKI - adjunct professor at Department of National Security of the Jagiellonian University. Fields of scientific interest include international relations, international security, Russia and its foreign and security policy, military and technological dimensions of national and international security with special attention to missile defence and space security. Author of the book Missile Defence in International Relations (2015). 